\title{
Age and geochemistry of Late Neoproterozoic and Early Cambrian igneous rocks in southern New Brunswick: similarities and contrasts
}

\author{
Sandra M. Barr, ${ }^{1}$ Chris E. White, ${ }^{2}$ and Brent V. Miller ${ }^{3}$ \\ 1. Department of Geology, Acadia University, Wolfville, Nova Scotia B4P 2R6 Canada \\ 2. Department of Natural Resources, P.O. Box 698, Halifax, Nova Scotia B3N 2T9 \\ 3. Department of Geological Sciences, University of North Carolina, Chapel Hill, North Carolina, USA 27599-3315
}

Date received:June 29, 2003 S Date accepted: November 9, 2003

\begin{abstract}
Late Proterozoic to Early Cambrian igneous rocks are major components of the fault-bounded Caledonia, Brookville, and New River terranes of southern New Brunswick. As previously demonstrated, ca. $620 \mathrm{Ma}$ and ca. 560-550 Ma volcanic and plutonic rocks of the Caledonia terrane are petrologically similar to coeval units elsewhere in the Avalon terrane sensu stricto of the northern Appalachian orogen. In contrast, the Golden Grove Plutonic Suite and volcanic rocks of the Dipper Harbour Formation in the Brookville terrane are mainly younger, ranging in age from ca. $555 \mathrm{Ma}$ to $525 \mathrm{Ma}$. A new U-Pb (zircon) age reported here confirms that rhyolite in the Dipper Harbour Formation crystallized at $553 \pm 3 \mathrm{Ma}$, like the older units of the Golden Grove Plutonic Suite to which they are chemically similar. However, they differ chemically from felsic units of similar age in the Caledonia terrane, with higher $\mathrm{K}_{2} \mathrm{O}$ and $\mathrm{Rb}$, lower $\mathrm{Na}_{2} \mathrm{O}$, and negative epsilon $\mathrm{Nd}$ values, although they also appear to have formed in an extensional setting. The Early Cambrian history of the two terranes is also very different, with clastic sediment deposition dominating in the Caledonia terrane while an active continental margin subduction zone developed on the Brookville terrane.

$\mathrm{A} \mathrm{U}-\mathrm{Pb}$ (zircon) age of $539 \pm 4$ Ma shows that volcanic rocks in the Simpsons Island Formation in the New River terrane are early Cambrian, similar to the ages of some plutons of the Golden Grove Plutonic Suite. More petrological studies of the Simpsons Island Formation are needed to assess it tectonic setting and relationship to the older (ca. $555 \mathrm{Ma}$ ) Leavitts Head Formation and Ragged Falls Plutonic Suite. These units are chemically similar to one another, consistent with their inferred comagmatic relationship, and are interpreted to have formed in an extensional setting. They are more similar to ca. 555-545 Ma volcanic and plutonic rocks of the Brookville terrane than to 560-550 Ma volcanic and plutonic rocks of the Caledonia terrane, although all of these units apparently formed in extensional settings. Too few data are available from volcanic units in the northeastern part of the New River terrane (Lobster Brook Formation) to compare them to the Leavitts Head Formation or to assess their tectonic setting.

$\mathrm{A} \mathrm{U}-\mathrm{Pb}$ age of $622 \pm 2 \mathrm{Ma}$ from the Blacks Harbour Granite in the southern part of the New River terrane is similar to previously reported ages from the Lingley Suite in the northeastern part of the terrane. More mapping and sampling are needed to define the extent of these ca. $625 \mathrm{Ma}$ units in the New River terrane and assess their tectonic setting, although a subduction environment is suggested by the available data.
\end{abstract}

\section{RÉSUMÉ}

Les roches ignées du Protérozoïque tardif au Cambrien précoce constituent des éléments importants des terranes limités par des failles de Caledonia, de Brookville et de New River dans le Sud du Nouveau-Brunswick. Il a déjà été démontré que les roches volcaniques et plutoniques d'environ $620 \mathrm{Ma}$ et de 560 à $550 \mathrm{Ma}$ du terrane de Caledonia sont pétrologiquement semblables aux unités contemporaines ailleurs à l'intérieur du terrane d'Avalon, faisant partie, au sens strict, du nord de l'orogène des Appalaches. Par contraste, le cortège plutonique de Golden Grove et les roches volcaniques de la Formation de Dipper Harbour dans le terrane de Brookville sont essentiellement plus récentes; leurs âges varient entre $755 \mathrm{Ma}$ et $525 \mathrm{Ma}$. Une nouvelle datation au U-Pb (à partir de zircon) signalée aux présentes confirme que la rhyolite de la Formation de Dipper Harbour s'est cristallisée vers $553 \pm 3 \mathrm{Ma}$, tout comme les unités plus anciennes du cortège plutonique de Golden Grove auxquelles ces roches ressemblent sur le plan chimique. Elles diffèrent toutefois du point de vue chimique des unités felsiques d'âge analogue du terrane de Caledonia, en présentant des concentrations plus élevées de $\mathrm{K}_{2} \mathrm{O}$ et de $\mathrm{Rb}$, des concentrations inférieures de $\mathrm{Na}_{2} \mathrm{O}$, et des valeurs $\mathrm{Nd}$ epsilon négatives, même si elles semblent s'être formées dans un cadre d'extension. Le passé des deux terranes au cours du Cambrien précoce est également très différent : un dépôt de sédiments clastiques prédomine dans le terrane de Caledonia, tandis qu'une zone active de subduction de la marge continentale s'est développée dans le terrane de Brookville. 


\begin{abstract}
Une datation au U-Pb (à partir de zircon) situant les roches volcaniques de la Formation de Simpsons Island dans le terrane de New River à $539 \pm 4 \mathrm{Ma}$, révèle qu'elles remontent au Cambrien, ce qui leur confère des âges semblables à certains plutons du cortège plutonique de Golden Grove. Il faudrait réaliser d'autres études pétrologiques de la Formation de Simpsons Island pour évaluer son cadre tectonique et ses rapports avec la Formation plus ancienne (environ $555 \mathrm{Ma}$ ) de Leavitts Head et le cortège plutonique de Ragged Falls. Ces unités sont chimiquement semblables les unes aux autres, ce qui correspond à leur présumée relation comagmatique. Elles sont interprétées comme des unités s'étant formées dans un cadre d'extension. Elles ressemblent plus aux roches plutoniques et volcaniques d'environ 555 à $545 \mathrm{Ma}$ du terrane de Brookville qu'aux roches plutoniques et volcaniques de 560 à $550 \mathrm{Ma}$ du terrane de Caledonia, même si ces unités se sont apparemment constituées dans des cadres d'extension. On dispose de trop peu de données des unités volcaniques du nord-est du terrane de New River (Formation de Lobster Brook) pour les comparer à la Formation de Leavitts Head ou pour évaluer leur cadre tectonique.

L'âge au U-Pb de $622 \pm 2 \mathrm{Ma}$ du granite de Blacks Harbour dans le sud du terrane de New River est semblable aux âges précédemment signalés dans le cas du cortège de Lingley dans le nord-est du terrane. D'autres travaux de cartographie et d'échantillonnage s'avèrent nécessaires pour définir l'étendue de ces unités d'environ $625 \mathrm{Ma}$ dans le terrane de New River ainsi que pour évaluer leur cadre tectonique, même si les données dont on dispose laissent supposer un environnement de subduction.
\end{abstract}

\section{INTRODUCTION}

Late Neoproterozoic igneous rocks are abundant in the Caledonia, Brookville, and New River terranes of southern New Brunswick (Figs. 1, 2). Some workers (e.g., Barr and White 1996; Samson et al. 2000) have proposed that differences in age and composition of these igneous rocks among the terranes are indicative of unrelated origins, and hence that each terrane had a separate history into the Paleozoic. Other workers (e.g., Eby and Currie 1996; Currie and McNicoll 1999; Whalen et al. 1996; Johnson 2001) emphasized linkages in age and composition among the plutonic and volcanic rocks, and suggested that these similarities indicate that at least parts of these terranes were together in the late Neoproterozoic.

This difference in interpretation has implications for the number of crustal blocks or terranes involved in building the Appalachian orogen, and hence for interpretations of Silurian and Devonian orogenic events. Some tectonic models have suggested that the Late Neoproterozoic rocks in outboard parts of the northern Appalachian orogen were all part of a single block (inset, Fig. 1), variously termed Avalon zone (Williams 1979), Avalon microcontinent (e.g., Landing 1996), West Avalonia (e.g., Murphy et al. 1999; Nance et al. 2002) or Avalon composite terrane (e.g., Dorais et al. 2001; Robinson et al. 1998). According to these authors, "Avalonia" interacted with the Laurentian margin as a single continental entity in the mid-Paleozoic. In contrast, other models have postulated that at least two separate blocks amalgamated independently and sequentially with the Laurentian margin in the Paleozoic (e.g., van Staal et al. 1998; Barr et al. 1998, 2002). These authors suggested that the New River and possibly Brookville terranes are related to a separate crustal block (Ganderia or Bras d'Oria), and that only the Caledonia terrane is part of Avalon terrane sensu stricto, as exemplified by the part of Newfoundland east of the Dover-Hermitage Bay Fault (Williams 1978).

The purpose of this paper is to further investigate relationships among the Caledonia, Brookville, and New River terranes of southern New Brunswick in the Late Neoproterozoic and Early Cambrian by comparing the igneous units formed in those areas during that time. To better constrain unit ages, three new U-Pb (zircon) ages are presented for igneous rocks in the Brookville and New River terranes, and a compilation of the new and previous U-Pb ages is used to compare ages of igneous units in the three terranes. In addition, new chemical data are presented for igneous units in the New River terrane, and combined with earlier data to make a chemical comparison among the three terranes. Although such comparisons were made previously between the Brookville and Caledonia terranes (Barr and White 1996; White and Barr 1996), new work in the New River terrane (Johnson and McLeod 1996; Johnson 2001, 2003; Currie and McNicoll 1999) now enables a preliminary comparison among all three terranes. Also, since the earlier comparisons, additional mapping, geochemistry, and $\mathrm{U}-\mathrm{Pb}$ dating have resulted in a better understanding of the Brookville terrane (White et al. 2002). Based on these comparisons, we suggest that igneous activity in the three terranes was not directly related, in support of other geological evidence that the three terranes were separate in the Late Neoproterozoic and Early Paleozoic.

\section{GEOLOGICAL OVERVIEW}

\section{Caledonia terrane}

The Caledonia terrane (Fig. 2a) includes mainly Neoproterozoic and Cambrian rocks located south of the Caledonia-Clover Hill fault, which has been interpreted to mark a cryptic suture between the Caledonia and Brookville terranes (White et al. 2001). Based on differences in lithology and age, Neoproterozoic volcanic and sedimentary rocks of the Caledonia terrane have been divided into the ca. $620 \mathrm{Ma}$ Broad River Group, exposed mainly in the northeastern and southern parts of the terrane, and the ca. 560-550 Ma Coldbrook Group which forms most of the western and northern parts (Bevier and Barr 1990; Barr et al. 1994; Barr and White 1999). Ca. 620 Ma compositionally expanded gabbroic to granitic plutons and ca. 560-550 Ma bimodal gabbroic and granitic plutons 


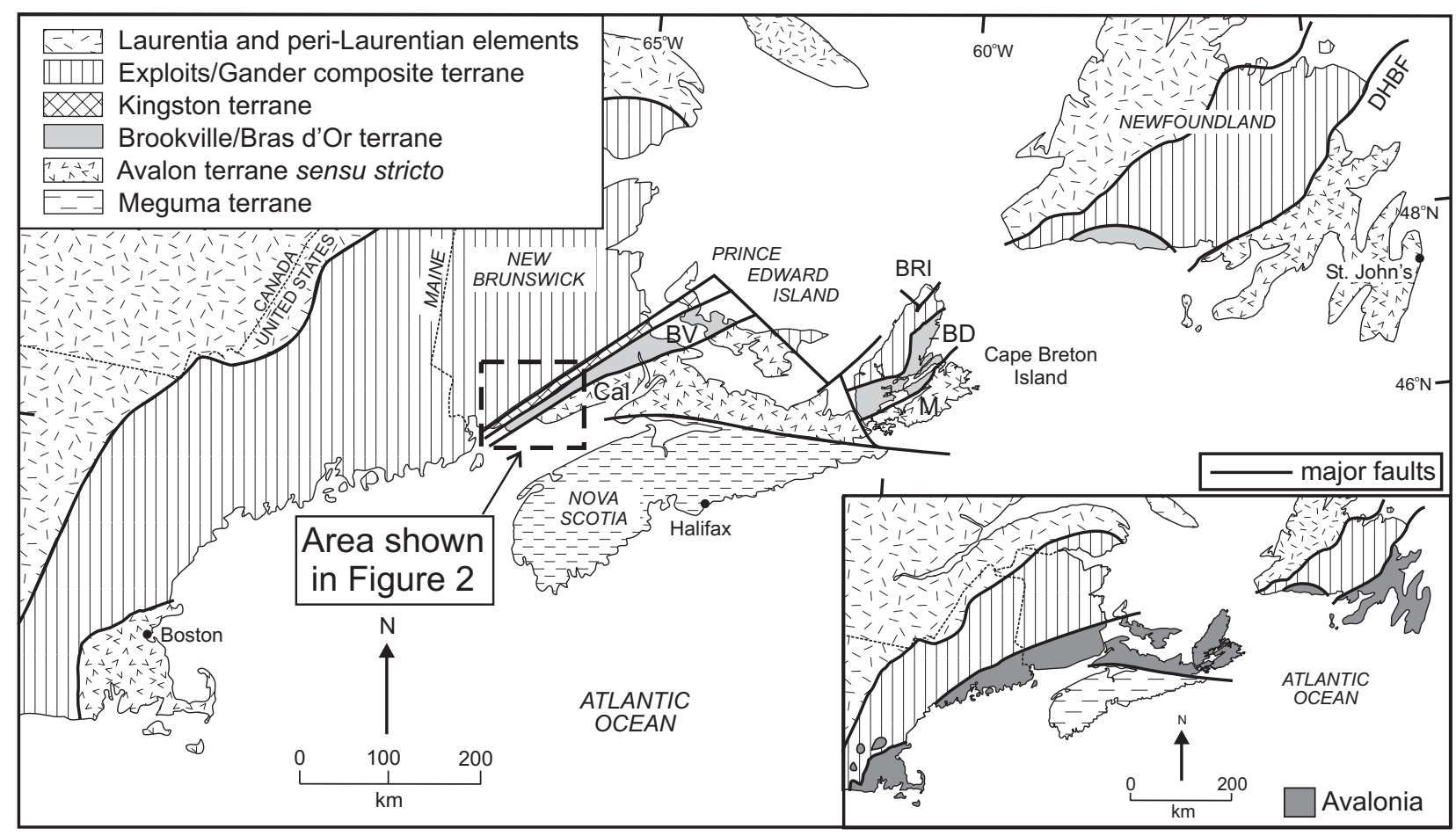

Fig. 1 Simplified map showing terranes of the northern Appalachian orogen modified from Barr et al. (2002). Heavy solid lines are inferred terrane boundaries. New River terrane of southern New Brunswick is included in the Exploits/Gander composite terrane on this figure. Abbreviations: BV, Brookville terrane; BD, Bras d'Or terrane ; BRI, Blair River inlier; Cal, Caledonia terrane; DHBF, Dover-Hermitage Bay Fault; M, Mira terrane. Inset map shows parts of the orogen typically included in broader definitions of West Avalonia, Avalon Zone, or Avalon composite terrane, as described in the text.

are interpreted to be cogenetic with the Broad River Group and basalt and rhyolite of the upper part of the Coldbrook Group, respectively (Barr and White 1999). On the basis of petrological characteristics, the ca. $620 \mathrm{Ma}$ rocks are interpreted to have formed in a continental margin magmatic arc, whereas the ca. 560-550 Ma rocks formed during subsequent extension (Barr and White 1999). The Coldbrook Group is overlain by a Lower Paleozoic platformal sedimentary sequence containing an "Avalonian" fauna (e.g., Tanoli and Pickerill 1988; Landing 1996; Landing and Westrop 1998).

A fault-bounded area of high-pressure and low-temperature metamorphic rocks located near the northwestern margin of the Caledonia terrane has been interpreted to represent an accretionary complex formed at ca. $620 \mathrm{Ma}$ in association with a southeast-dipping subduction zone that generated the Broad River Group and related plutons (White et al. 2001). This unit is evidence for a terrane boundary between the Caledonia and now-adjacent Brookville terrane.

\section{Brookville terrane}

In contrast to the Caledonia terrane, the Brookville terrane is characterized by mainly metasedimentary rocks (Green Head Group) and abundant plutons (White and Barr 1996; White et al. 2002). The terrane-bounding brittle faults, Caledonia - Clover Hill on the southeast and Kennebecasis on the northwest (Fig. 1), are Carboniferous or younger faults interpreted to mark the approximate locations of older cryptic sutures. The Green Head Group consists of the Ashburn (dominantly marble with minor metaclastic rocks) and Martinon (dominantly metasiltstone with minor calc-silicate rocks, quartzite, conglomerate, and marble) formations, interpreted to be lateral facies equivalents. The early Neoproterozoic or late Mesoproterozoic age proposed for the Green Head Group based on locally preserved stromatolite occurrences (Hofmann 1974) is supported by a minimum U-Pb age of $1230 \mathrm{Ma}$ for detrital zircon grains in a quartzite sample (Barr et al. 2003). The Green Head Group is in tectonic contact along the MacKay Highway shear zone (Nance and Dallmeyer 1994; White 1996) with the Brookville Gneiss, a locally migmatitic paragneiss with sheets of granodioritic to tonalitic orthogneiss, minor calc-silicate and marble layers, and rare quartzite and amphibolite. The paragneiss comprises about $75 \%$ of the Brookville Gneiss, and contains detrital zircon indicating a maximum depositional age of ca. $640 \mathrm{Ma}$ (Bevier et al. 1990). The orthogneiss has an igneous crystallization age of $605 \pm 3$ $\mathrm{Ma}$, and was metamorphosed to amphibolite facies at $564 \pm 6$ Ma (Bevier et al. 1990; Dallmeyer et al. 1990). These ages indicate that the Brookville Gneiss is younger than the Green Head Group and, hence, does not represent its basement, although the original relationship between the two units remains problematic (White and Barr 1996). 


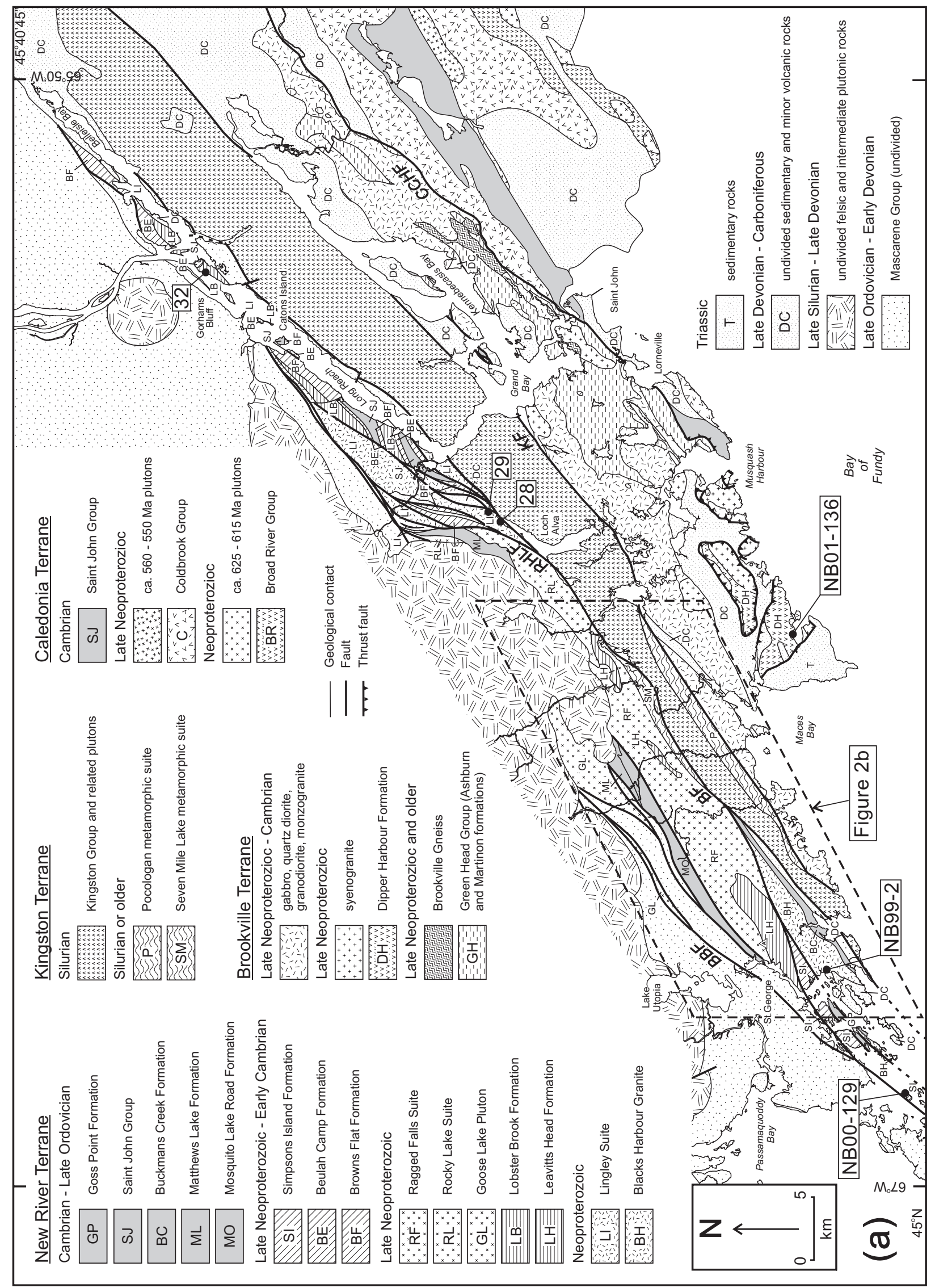




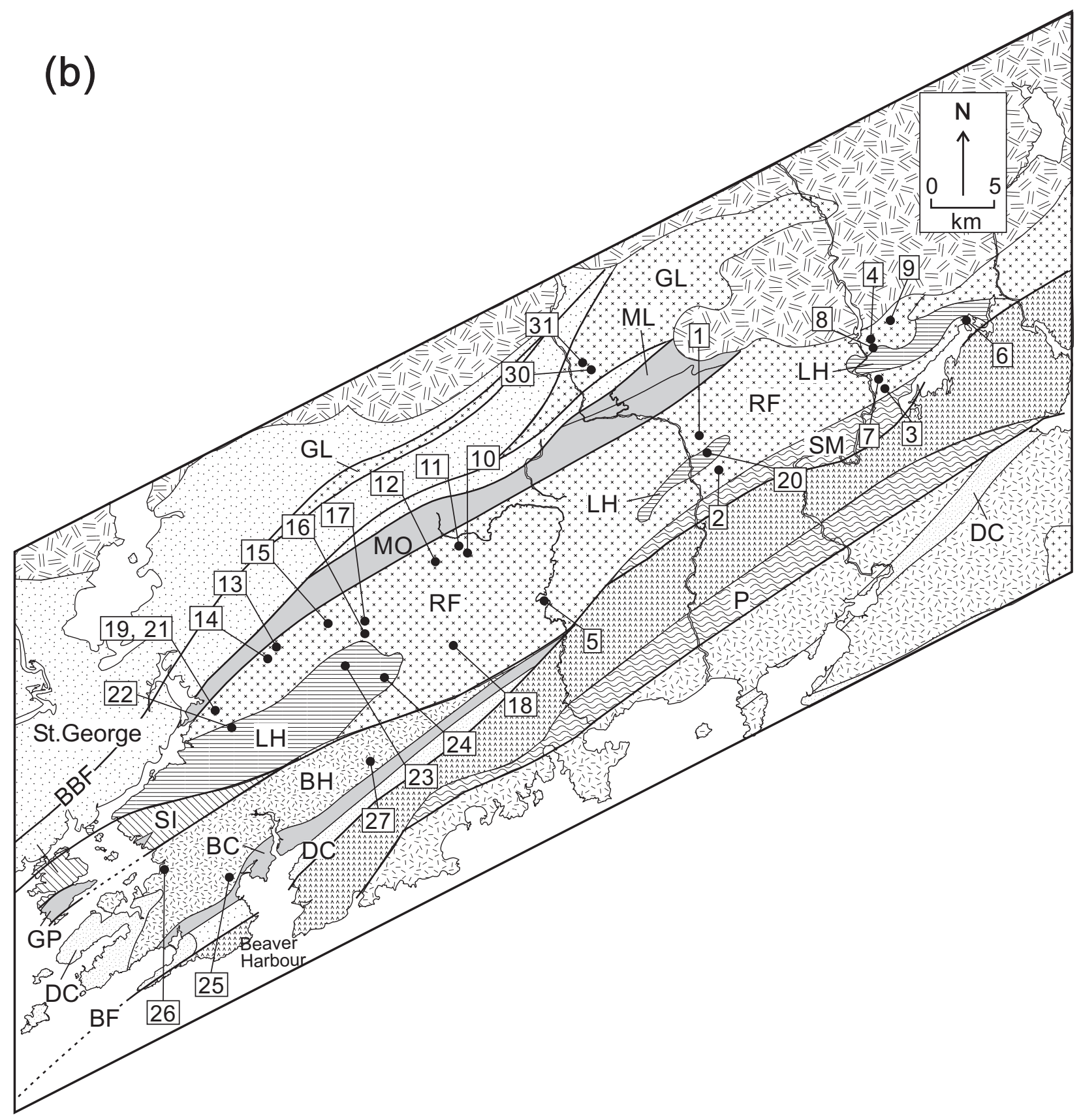

Fig. 2 (a) Simplified geological map of part of southern New Brunswick, showing the distribution of major units in the southwestern parts of the New River, Brookville, and Caledonia terranes. Geology for the New River terrane is after Johnson (2001), for the Brookville terrane after White et al. (2002), and for the Caledonia terrane after Barr and White (1999). Locations are indicated for the three dated samples NB00-129, NB99-2, and NB01-136 and geochemistry samples 28, 29, and 32. Abbreviations: BBF, Back Bay Fault; BF, Bellisle Fault; CCHF, Caledonia - Clover Hill Fault; KF, Kennebecasis Fault; RHLF, Robin Hood Lake Fault. (b) Enlarged view of the dashed area on Fig. 2a, showing locations of geochemistry samples other than 28, 29, and 32. Unit designations, patterns, and abbreviations are the same as on Fig. 2a. 
The Green Head Group and Brookville Gneiss have been intruded by plutons of the redefined Golden Grove Plutonic Suite (White et al. 2002). The plutons range in composition from gabbroic to granitic, and have yielded U-Pb and ${ }^{40} \mathrm{Ar} /{ }^{39} \mathrm{Ar}$ dates of ca. 550 Ma to $527 \mathrm{Ma}$ (Dallmeyer and Nance 1992; White 1996; Currie and Hunt 1991; Currie and McNicoll 1999; White et al. 2002). Petrological characteristics suggest that they constitute a calc-alkalic I-type granitoid suite, probably emplaced in a continental margin subduction zone (White 1996; Eby and Currie 1996), although the older components of the suite (ca. $550 \mathrm{Ma}$ ) have characteristics indicative of an early extensional environment that evolved to subduction (White et al. 2002). Eby and Currie (1996) and Currie and McNicoll (1999) suggested that the plutons of the Brookville terrane are related to those in the Caledonia and New River terranes, but Barr and White (1996) argued that they are mainly younger and part of a separate and unrelated tectonic regime. Volcanic rocks of the Dipper Harbour Formation, locally preserved in faulted blocks in the southwestern part of the Brookville terrane (Fig. 2), are chemically similar to the early felsic granitoid components of the terrane (White et al. 2002). However, other workers have suggested that the Dipper Harbour Formation is related to volcanic rocks of broadly similar age in the Coldbrook Group of the Caledonia terrane, although the ages reported for samples from the Dipper Harbour Formation and associated plutons had large errors associated with them (Zain Eldeen 1991; Currie and Hunt 1991).

\section{New River terrane}

The most northwesterly exposures of Precambrian rocks known in southern New Brunswick occur in the New River terrane. Rock units in the New River terrane have been described by Johnson and McLeod (1996) and Johnson (2001;2003), and the interpretations of these authors are generally followed here (Fig. 2).

The New River terrane is cut by numerous faults, and hence relationships among units are uncertain in many cases. The southern part of the belt is dominated by the Blacks Harbour Granite and Ragged Falls suite (Fig. 2). The Blacks Harbour Granite occurs with minor felsic volcanic rocks in a faultbounded strip on the southern margin of the terrane. Prior to the new age reported here, it was undated. The Ragged Falls suite, as defined by Johnson $(2001,2003)$, includes syenogranite, monzogranite, tonalite, and gabbro. Ages of $555 \pm 2 \mathrm{Ma}$ and $555 \pm 10$ Ma have been reported for granodiorite and granite, respectively, from the suite (Johnson and McLeod 1996; Currie and Hunt 1991). The Ragged Falls Suite is closely associated with volcanic rocks (Leavitts Head Formation of Johnson 2001, 2003), a felsic component of which has yielded a U-Pb age of ca. $550 \mathrm{Ma}$ (Johnson and McLeod 1996). Also in the area are numerous faulted blocks of volcanic and sedimentary rocks that were assigned to the Ordovician Simpsons Island volcanics and Goss Point Formation by Johnson and McLeod (1996). Based on the U-Pb (zircon) age reported here, Johnson (2003) separated the Simpsons Island volcanics (Simpsons Island
Formation) from the fossiliferous Late Ordovician rocks of the Goss Point Formation (Nowlan et al. 1997).

A fault-bounded belt of Early Cambrian and Silurian volcanic and sedimentary rocks separates the Ragged Falls suite and Leavitts Head Formation from the Goose Lake Pluton (undated granodiorite and granite) to the north (Fig. 2a). To the northeast, Johnson $(2001,2003)$ interpreted the Ragged Falls suite to pass gradationally into similar granitoid rocks of the undated Rocky Lakes Suite, which she described as granite, granodiorite, tonalite, and quartz diorite, cut by numerous mafic dykes. Farther to the northeast, Johnson $(2001,2003)$ terminated the Rocky Lakes suite at the major northeast-trending Robin Hood Lake Fault (Fig. 2a). Northeast of this fault, ca. 625 Ma granitoid rocks are in complexly faulted relationships with ca. $555 \mathrm{Ma}$ felsic tuff and porphyry, Neoproterozoic to Cambrian mafic and felsic volcanic and sedimentary rocks, and Cambrian rocks assigned to the Saint John Group (Tanoli and Pickerill 1988; Johnson and McLeod 1996; Johnson 2001, 2003). The ca. 625 Ma granitoid rocks were termed the Lingley and Brittain Creek plutons by Currie and McNicoll (1999). However, chemical data from granitic samples reported by Eby and Currie (1996) to be from the Lingley Pluton are at least in part from younger quartz-eye granitic porphyry that Johnson (2001) included with the Lobster Brook Formation. A sample from the Lobster Brook Formation which yielded a U-Pb age of ca. $550 \mathrm{Ma}$ (McLeod et al. in press).

As a result of her work, Johnson $(2001,2003)$ suggested that the New River terrane is composite. She proposed that units northeast of the Robin Hood Lake Fault, as well as the Blacks Harbour Granite and spatially associated units in the Beaver Harbour area (Fig. 2b), are part of the Avalon zone, and hence comparable to rocks in the Caledonia terrane. In contrast, units southwest of the fault and north of the Blacks Harbour Granite may be related to the Brookville terrane and/or the St. Croix terrane and related units in Maine, which have been linked to the Gander terrane (van Staal et al. 1998; Fyffe et al. 1999).

\section{U-PB GEOCHRONOLOGY}

\section{Introduction}

Samples from the Simpsons Island Formation and Blacks Harbour Granite in the New River terrane and the Dipper Harbour Formation in the Brookville terrane (Fig. 2) were dated by the U-Pb (zircon) method as part of the present study. The analyses were done at the University of North Carolina (Chapel Hill) Isotope Geochemistry Laboratory. Zircon grains were separated from samples weighing ca. $25 \mathrm{~kg}$ using standard techniques, and hand picked under a binocular microscope in order to select groups of grains that were similar in morphology and as clear, crack-free, and inclusion-free as possible. All zircon fractions were highly abraded to remove the outermost portions of grains that are most likely to have been affected by $\mathrm{Pb}$-loss. Detailed analytical procedures were similar to those described by Miller et al. (2001). 


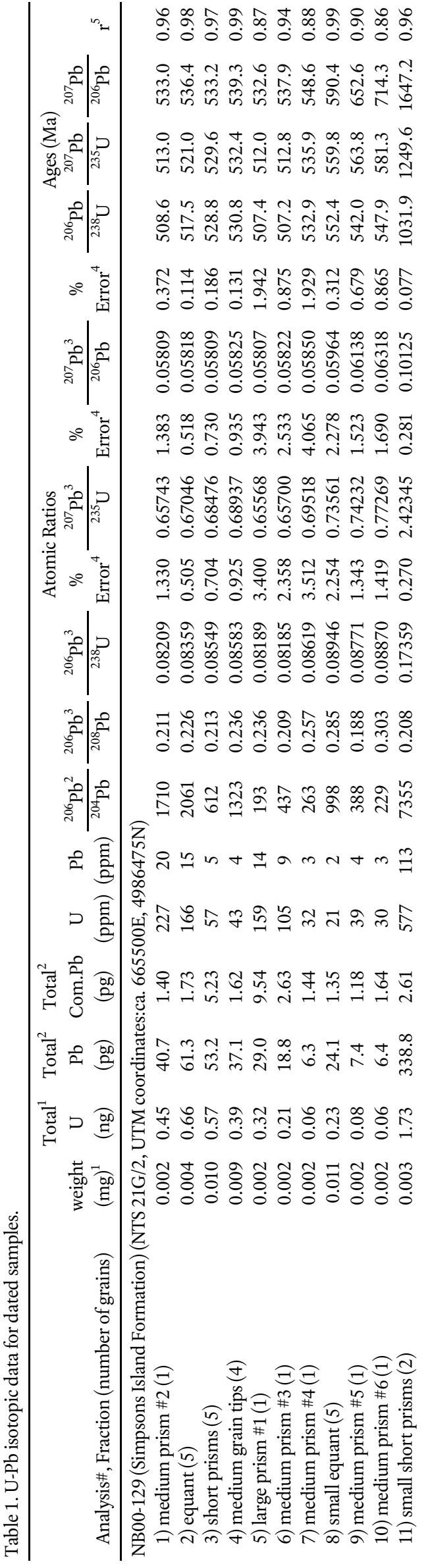

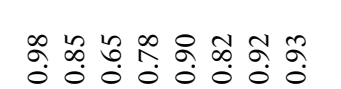

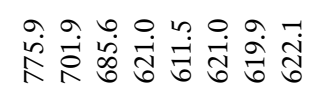

a요

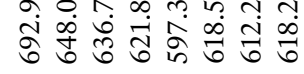

수웅요 누 बิं

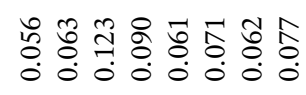

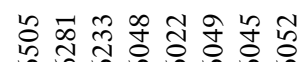

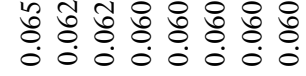

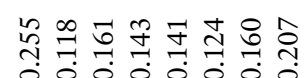

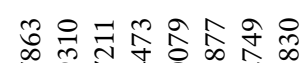

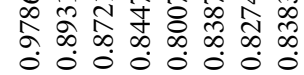

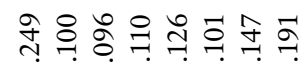

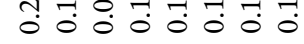

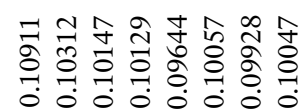
㐫莳

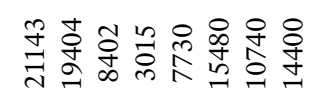

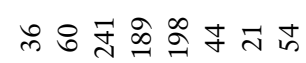

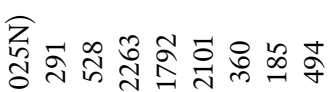
वे $n \infty n n+n o$

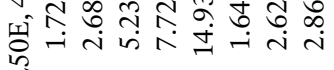

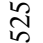

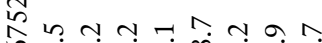

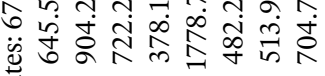

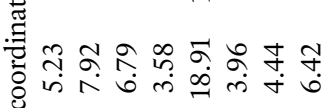

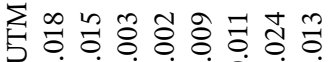

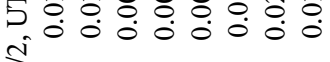

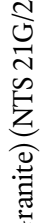

莣

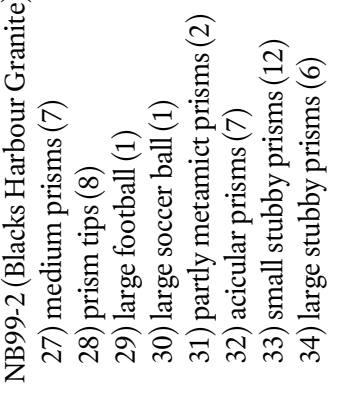

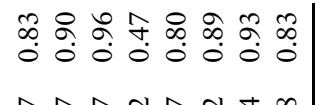

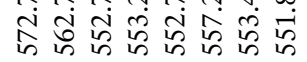

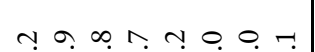

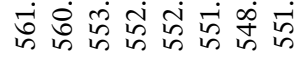
tr. 궁

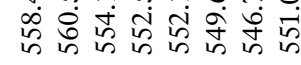

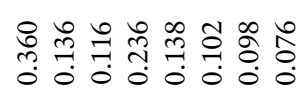

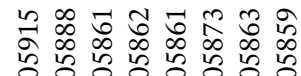

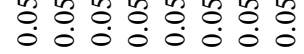

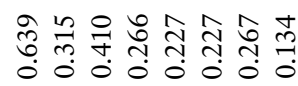

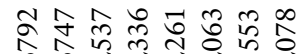
का

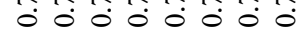

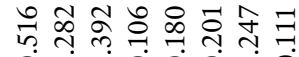

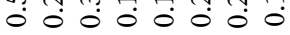

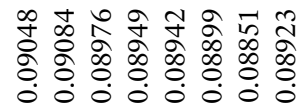

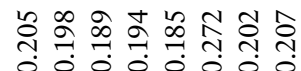
ని

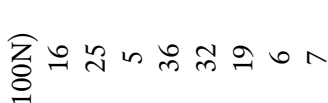

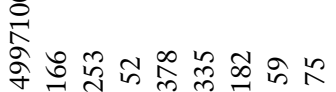
셩 홍

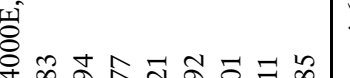

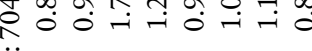
苟

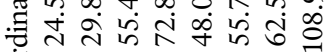
莡n 0 人。 n n

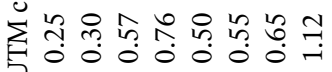

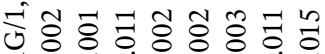

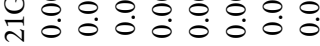

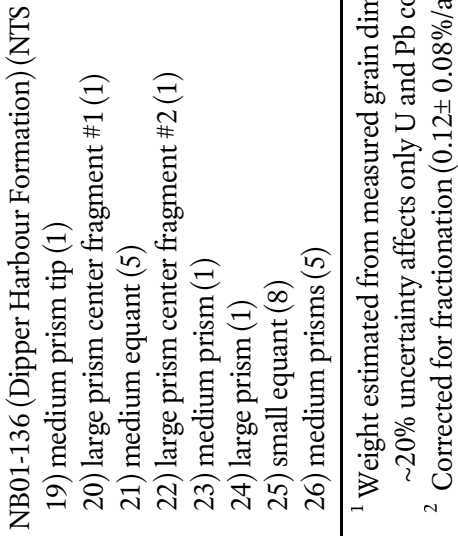



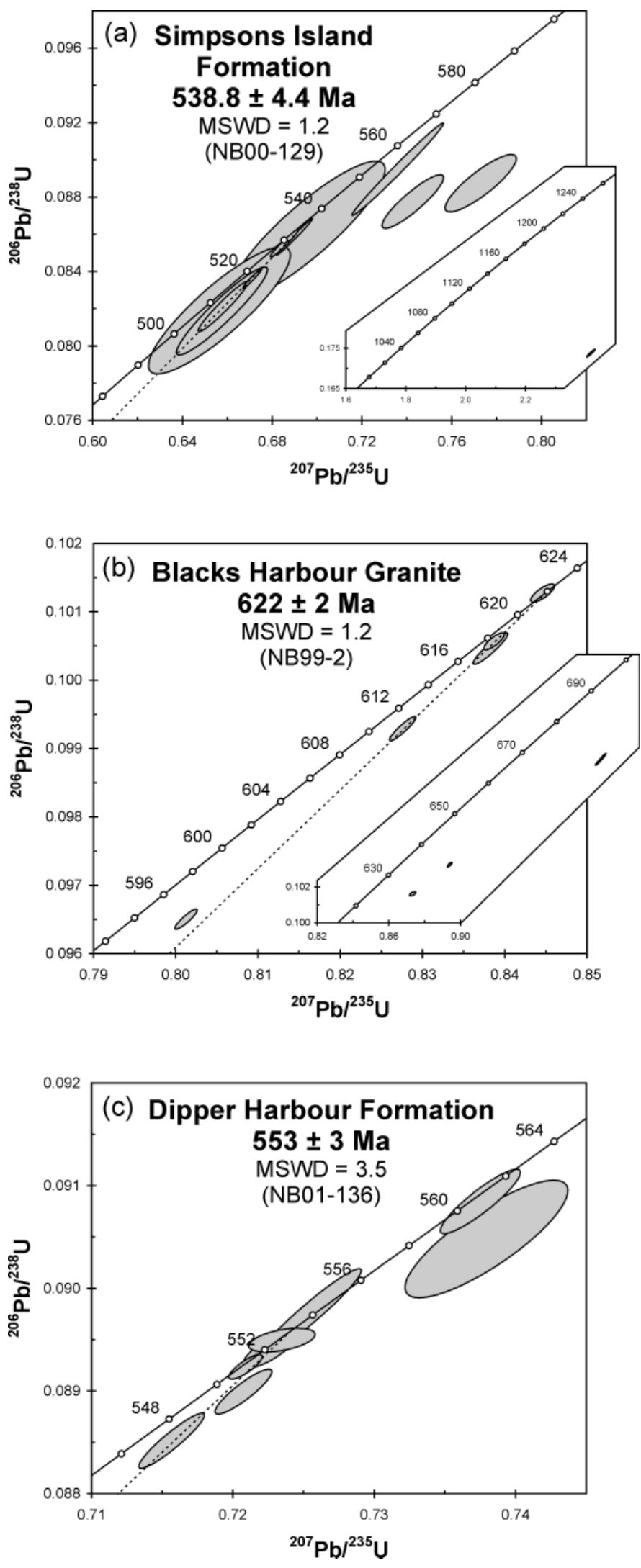

Fig. 3 Concordia diagrams for (a) NB00-129, (b) NB99-2, and (c) NB01-136, based on data presented in Table 1.

\section{Simpsons Island Formation (Sample NB00-129)}

Rhyolite sample NB00-129 was collected from the Simpsons Island Formation on Adam Island in the southwestern part of the New River terrane (Fig. 2). Johnson and McLeod (1996) interpreted this unit to be Ordovician, because of close spatial association with faulted slivers of sedimentary rocks that contain Late Ordovician fossils. The dated sample is a fine-grained flow-banded rhyolitic flow with well-developed eutaxitic and locally spherulitic texture.

Zircon grains separated from sample NB00-129 were mostly prismatic, and large enough $(\sim 150-200 \mu \mathrm{m} \times 30-40 \mu \mathrm{m})$ for analysis of single grains and fractions of a small number of grains (Table 1). Eleven fractions were analyzed and four appear to contain an inherited component (Fig. 3a). Three fractions have relatively large errors due to low radiogenic to common $\mathrm{Pb}$ ratios (Table 1). Two of the highest-precision analyses are nearly concordant and one relatively lower precision analysis is concordant within error. The seven analyses define a concordant-to-discordant trend with an upper intercept of $538.8 \pm 4.4 \mathrm{Ma}$ and a lower intercept suggestive of recent $\mathrm{Pb}$ loss. We consider the upper-intercept age as the time of zircon crystallization in the magma, and within error of the time of rhyolite extrusion.

This age indicates that the Simpsons Island Formation is earliest Cambrian in age (time scale of Okulitch 2002), consistent with the earlier interpretation of Currie (1997). The new age suggests that volcanic rocks in the area, assigned previously to the Simpsons Island and Goss Point formations, are of early Cambrian age (S. Johnson, personal communication 2003).

\section{Blacks Harbour Granite (Sample NB99-2)}

The Blacks Harbour Granite is located in a complexly faulted area, associated with unnamed and undated volcanic and sedimentary rocks, in faulted contact with Middle Cambrian mafic volcanic and sedimentary rocks. The volcanic and sedimentary unit, termed the Buckmans Creek beds (Currie 1988; Johnson 2001), has been interpreted to unconformably overlie the Blacks Harbour Granite (Greenough et al. 1985; Currie 1988; Johnson 2001). Helmstaedt (1968) described the granite as mainly alaskite, described intrusive contacts with adjacent units, and considered the pluton to be Devonian. The dated sample NB99-2 is coarse-grained granodiorite collected in the village of Blacks Harbour. It consists of plagioclase, quartz, and less abundant orthoclase in allotriomorphic granular texture with less than $5 \%$ chlorite (after biotite).

Zircon grains separated from sample NB99-2 were of a wide variety of morphologies and sizes (Table 1). Eight zircon fractions ranging from a large single grain to 12 small prismatic grains were analyzed (Fig. 3b). Three fractions have ${ }^{207} \mathrm{~Pb} /{ }^{206} \mathrm{~Pb}$ ages of $>685 \mathrm{Ma}$, which we interpret to contain an inherited component. One fraction is concordant at $\sim 622$ $\mathrm{Ma}$ and three others form a discordant line from that age. The four analyses yield an upper intercept age of $622 \pm 2 \mathrm{Ma}$ and a lower intercept suggesting recent $\mathrm{Pb}$ loss. One highly discor- 
dant fraction of partly metamict zircon grains plots to the left of this discordant trend, likely due to ancient $\mathrm{Pb}$-loss, the age of which cannot be estimated reasonably from the data at hand. We interpret the upper intercept age of $622 \pm 2 \mathrm{Ma}$ to be the time of crystallization of the Blacks Harbour Granite.

\section{Dipper Harbour Formation (Sample NB01-136)}

A previous U-Pb (zircon) age for the Dipper Harbour Formation had a large error (Zain Eldeen 1991). Leucogranite of the Musquash Harbour Pluton, which appears to have a gradational relationship with the volcanic rocks (Currie and Hunt $1991)$, also yielded an age with a very wide error $(555 \pm 15 \mathrm{Ma})$. In order to better constrain the ages of both of these important units, felsic tuff sample NB01-136 was collected for dating. The sample consists of scattered embayed quartz and less abundant feldspar clasts in a fine-grained groundmass of quartz and feldspar. Zircon grains separated from sample NB01-136 were mainly prisms of sufficient size $(70-150 \mu \mathrm{m} \times 20-40 \mu \mathrm{m})$ to do single-grain analyses or analyses of a small number of grains (Table 1). One analysis was a single pyramidal grain tip broken from a prismatic grain during sample processing. Of the eight analyzed zircon fractions, two appear to contain an inherited component (Fig. 3c). The remaining six form a discordant trend with an upper intercept age of $553 \pm 3 \mathrm{Ma}$. One fraction in this discordant trend lies slightly to the right of the others and may contain a small inherited component. It was, nevertheless, included in the regression, which causes a high mean square of weighted deviates (MSWD). By excluding this fraction, the upper intercept age remains essentially the same, but the MSWD is reduced to $<1$. We consider the upper-intercept age of $553 \pm 3 \mathrm{Ma}$ as the time of zircon crystallization in the magma, and within error of the age of the volcanic rock.

\section{Age compilation}

Previous U-Pb crystallization ages for igneous units in the Caledonia, Brookville, and New River terranes are compiled on Fig. 4, together with the three new ages reported here. Ages in the Caledonia terrane fall into two main groups - older ages in the range 625-615 Ma representing the Broad River Group and co-genetic plutons, and younger ages in the range 560-550 Ma representing the Coldbrook Group and co-genetic plutons. A crystallization age of ca. $600 \mathrm{Ma}$ reported for a tuffaceous sample previously assigned to the Broad River Group (Bevier and Barr 1990) may represent inherited zircon in a ca. 560-550 Ma unit of the Coldbrook Group. Ash beds in the overlying Cambrian Saint John Group yielded zircon ages of $533 \pm 2 \mathrm{Ma}$ (Samson 1995); $531 \pm 1 \mathrm{Ma}$ (Isachsen et al. 1994), and ca. 511 $\mathrm{Ma}$ (Landing et al. 1998), as well as a detrital zircon population at ca. $523 \mathrm{Ma}$ (Landing et al. 1998).

In the Brookville terrane, orthogneiss in the Brookville Gneiss yielded an age of ca. $605 \mathrm{Ma}$, interpreted to represent its igneous crystallization age (Bevier et al. 1990). However, plutons in the terrane yielded ages between ca. $553 \mathrm{Ma}$ and $527 \mathrm{Ma}$, reflecting a long-lived magmatic event. The new age presented here for the Dipper Harbour Formation also constrains the age of the Musquash Harbour and similar plutons in the area because of the gradational relationship between the volcanic and plutonic units in the Dipper Harbour area.

In the New River terrane, ca. $625 \mathrm{Ma}$ ages were reported for the Lingley and Brittain Creek plutons by Currie and McNicoll (1999); both plutons were included in the Lingley Suite by Johnson $(2001,2003)$. A similar age $(622 \mathrm{Ma})$ was obtained in the present study for the Blacks Harbour Granite in the southwestern part of the New River terrane. In contrast, ca. $555 \mathrm{Ma}$ ages have been obtained throughout the terrane, from the Lobster Brook Formation in the northeast and both the Ragged Falls suite and Leavitts Head Formation in the southwest. The new age reported here for the Simpsons Island Formation is significantly younger at ca. $539 \mathrm{Ma}$. The youngest dated volcanic unit in the terrane is the ca. 515 Ma Mosquito Lake Road Formation.

Close spatial relationships and chemical similarities support a co-magmatic relationship between volcanic and plutonic units of similar age in each of the Caledonia and Brookville terranes, with a range in $\mathrm{U}-\mathrm{Pb}$ ages from each suite that likely reflects protracted magmatic activity (Barr and White 1999; White et al. 2002). However this relationship has yet to be tested in the New River terrane. Furthermore, the relationship between igneous units of similar age in different terranes is problematic. Currie and McNicoll (1999) and Johnson (2001) emphasized that the presence of ca. $625 \mathrm{Ma}$ and $550 \mathrm{Ma}$ igneous rocks, combined with the presence of the Cambrian Saint John Group or equivalent units containing Avalonian fauna, in both terranes strongly suggests that at least parts of the New River terrane have close links with the Caledonia terrane. Ca. 550 Ma igneous rocks also occur in the Brookville terrane, and ca. 531 Ma zircon grains in ash layers in the Saint John Group of the Caledonia terrane have similarities to the ages of some plutonic units in the Brookville terrane.

One way to assess whether or not units of similar age are likely to be related to one another is to compare their chemical characteristics, as done in the subsequent section for igneous units in the Caledonia, Brookville, and New River terranes.

\section{GEOCHEMISTRY}

\section{Major and trace elements}

A large database of whole-rock chemical analyses is available for the Caledonia (Barr and White 1999) and Brookville (White 1996; White et al. 2002) terranes, but relatively few analyses have been published previously for volcanic and plutonic units in the New River terrane (Johnson and McLeod 1996; Eby and Currie 1996). To enable a preliminary comparison with units of similar ages in adjacent terranes, additional analyses were obtained for 32 granitoid and volcanic samples from units in the New River terrane (Table 2). However, the data are mainly from the southwestern part of the terrane, and units northeast of the Robin Hood Lake Fault are poorly represented. Most 


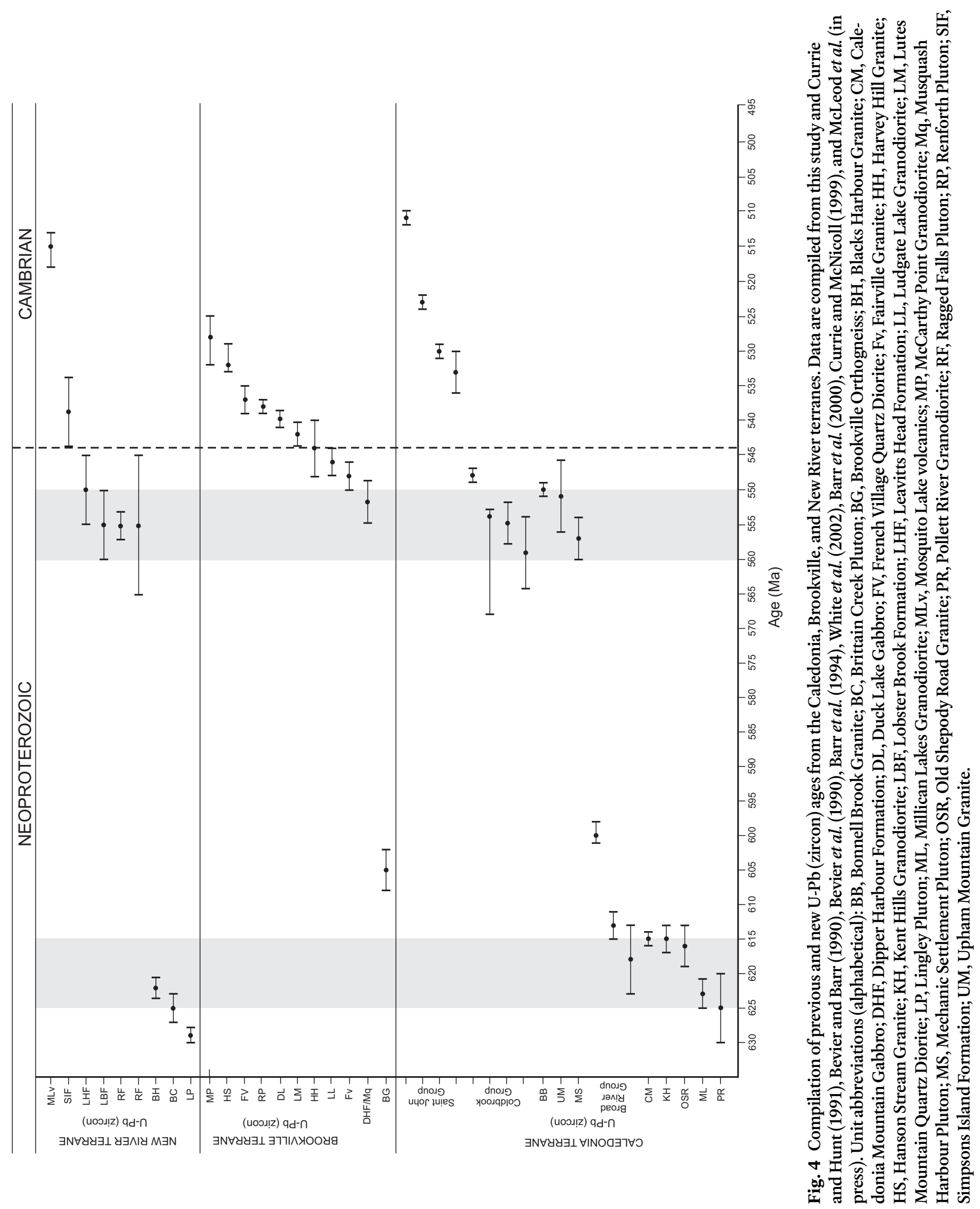




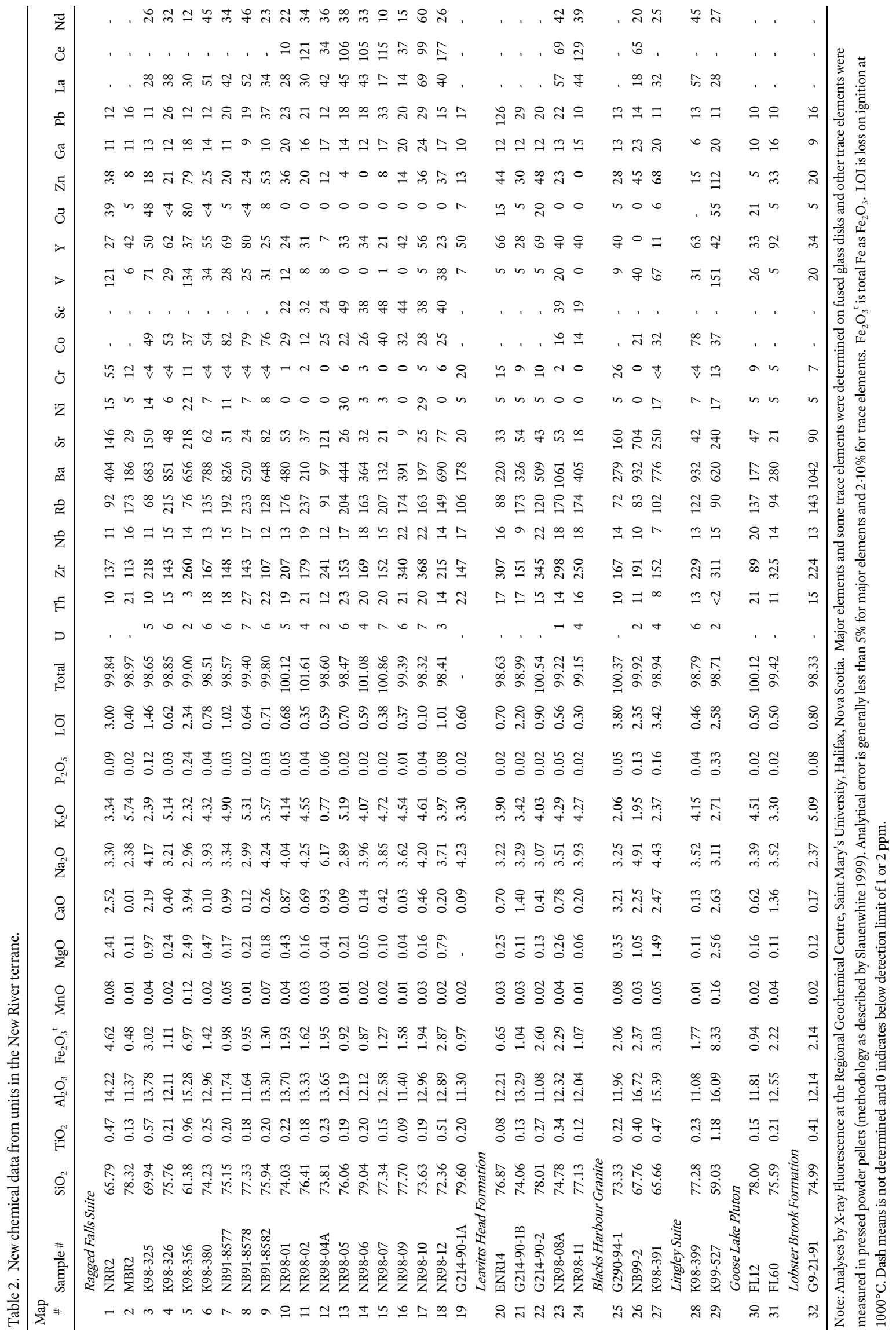




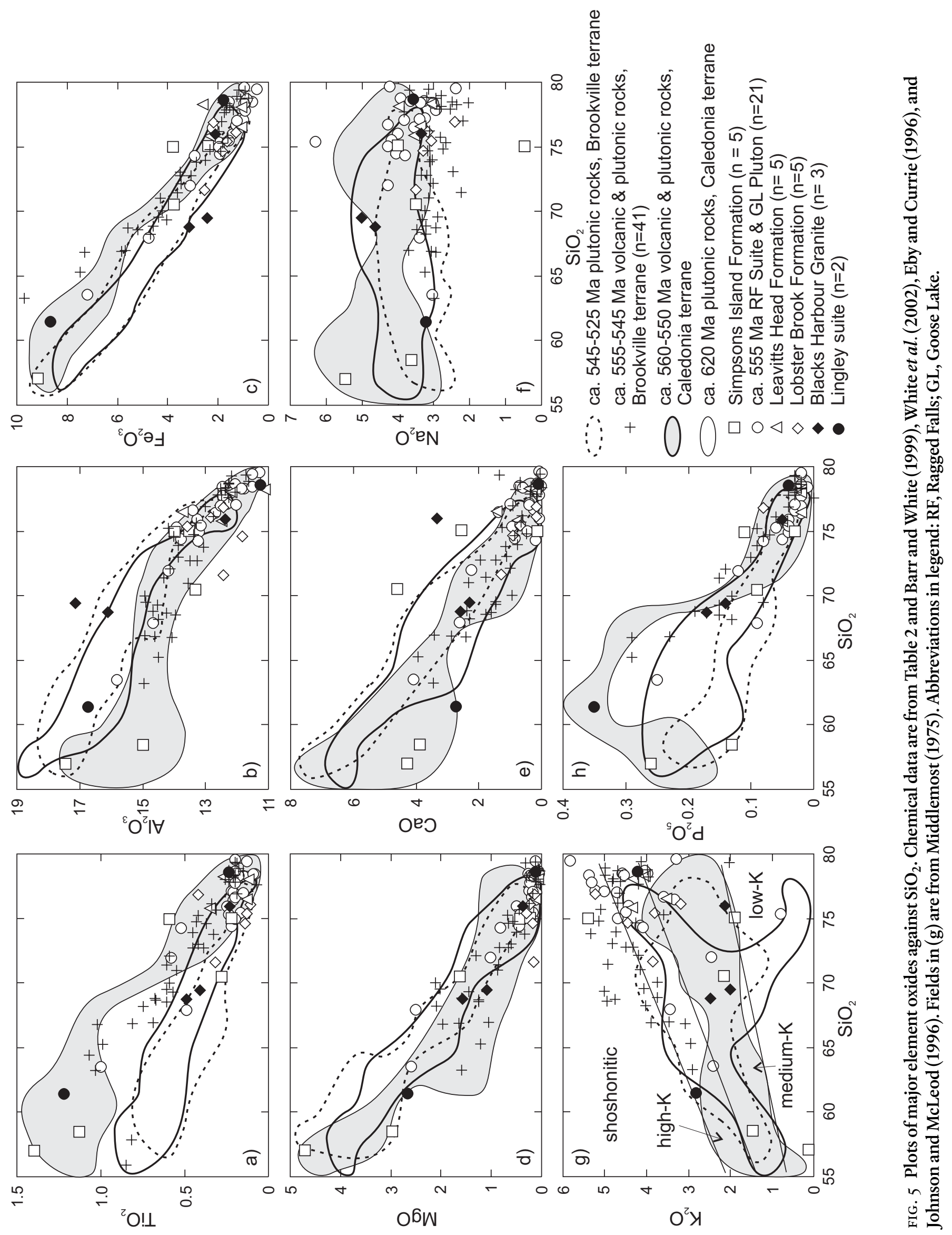



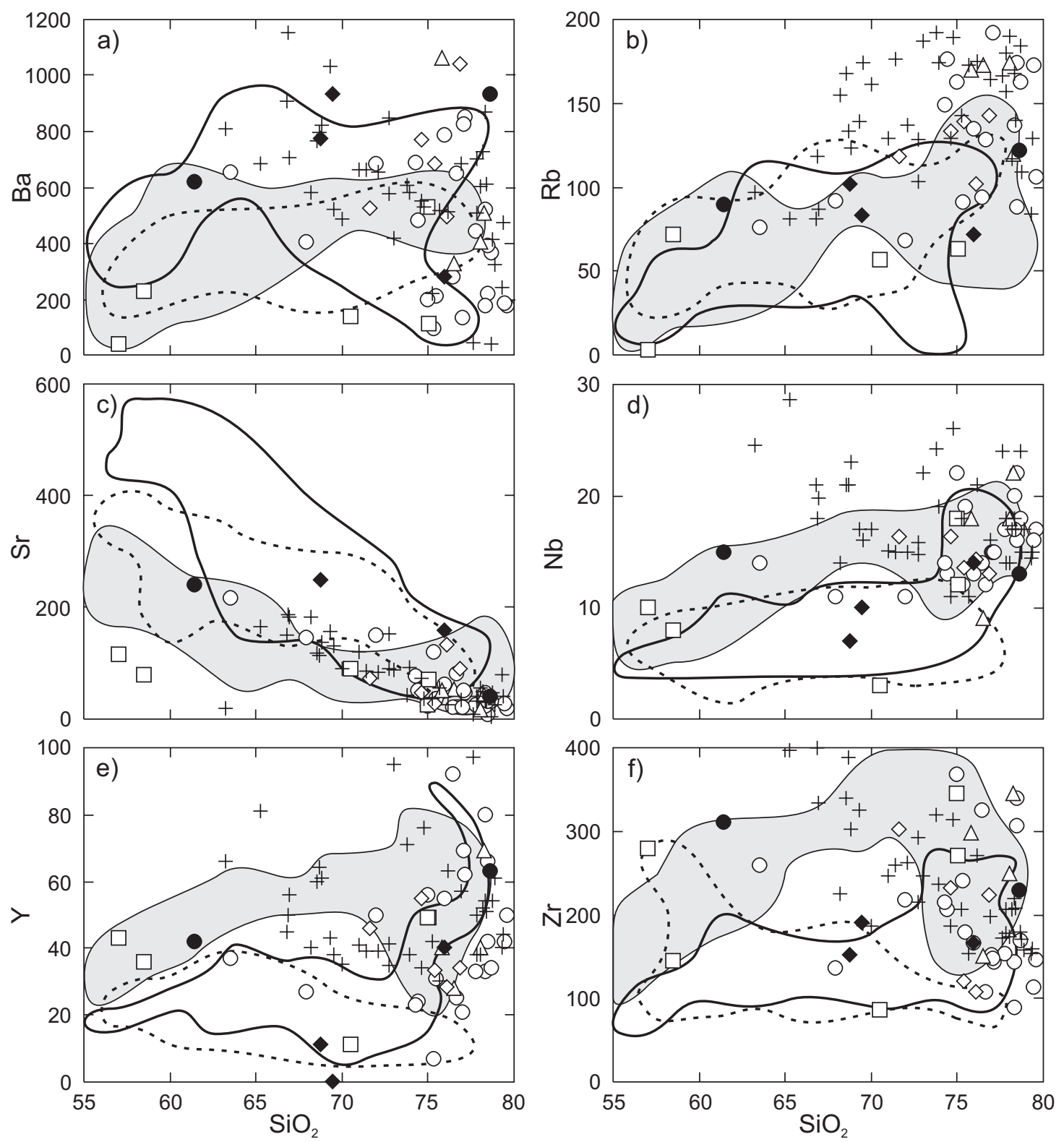

Fig. 6 Plots of $\mathrm{Ba}, \mathrm{Rb}, \mathrm{Sr}, \mathrm{Nb}, \mathrm{Y}$, and $\mathrm{Zr}$ against $\mathrm{SiO}_{2}$. Symbols and sources of chemical data are as in Fig. 5 .

of the analysed samples have high $\mathrm{SiO}_{2}$ content, over $74 \%$, reflecting the highly felsic compositions of the sampled units. Because the ages of mafic units are not well constrained, mafic samples were not included in the present study.

To illustrate compositional similarities and differences among the sample suites, major element oxides and selected trace elements are plotted against $\mathrm{SiO}_{2}$ (Figs. 5, 6). For visual clarity, suites with large numbers of analyses are represented by fields on the diagrams. Individual data points are shown for samples from the New River terrane and the Dipper Harbour Formation and related plutons of the Brookville terrane, as the smaller number of samples makes drawing fields less appropriate.

The ca. $620 \mathrm{Ma}$ granitoid suite from the Caledonia terrane and the ca. 545-525 Ma granitoid suite of the Brookville terrane show similar compositional trends in major element oxides, with overlapping fields for $\mathrm{TiO}_{2}, \mathrm{Al}_{2} \mathrm{O}_{3}, \mathrm{Fe}_{2} \mathrm{O}_{3}{ }^{\mathrm{t}}, \mathrm{MgO}$, $\mathrm{CaO}, \mathrm{Na}_{2} \mathrm{O}, \mathrm{K}_{2} \mathrm{O}$, and $\mathrm{P}_{2} \mathrm{O}_{5}$ on plots against $\mathrm{SiO}_{2}$ (Fig. 5). This similarity is consistent with the interpretations of Barr and White (1999) and White et al. (2002) that both suites formed in continental margin subduction zones. In contrast, the ca. 560-550 Ma volcanic and granitoid rocks of the Caledonia terrane show similar fields for $\mathrm{MgO}, \mathrm{CaO}, \mathrm{Na}_{2} \mathrm{O}$, and $\mathrm{K}_{2} \mathrm{O}$ but have higher $\mathrm{TiO}_{2}$ and $\mathrm{Fe}_{2} \mathrm{O}_{3}{ }^{\mathrm{t}}$, and lower $\mathrm{Al}_{2} \mathrm{O}_{3}$ (Fig. 5), interpreted to be indicative of their origin in an extensional setting. The ca. 555-545 Ma volcanic and granitoid rocks of the Brookville terrane (Dipper Harbour Formation and related plutons) also likely formed in an extensional setting, but differ from the Caledonia terrane units of similar age in that they show limited range in $\mathrm{SiO}_{2}$, lower $\mathrm{Na}_{2} \mathrm{O}$, and higher $\mathrm{K}_{2} \mathrm{O}$ (Fig. 

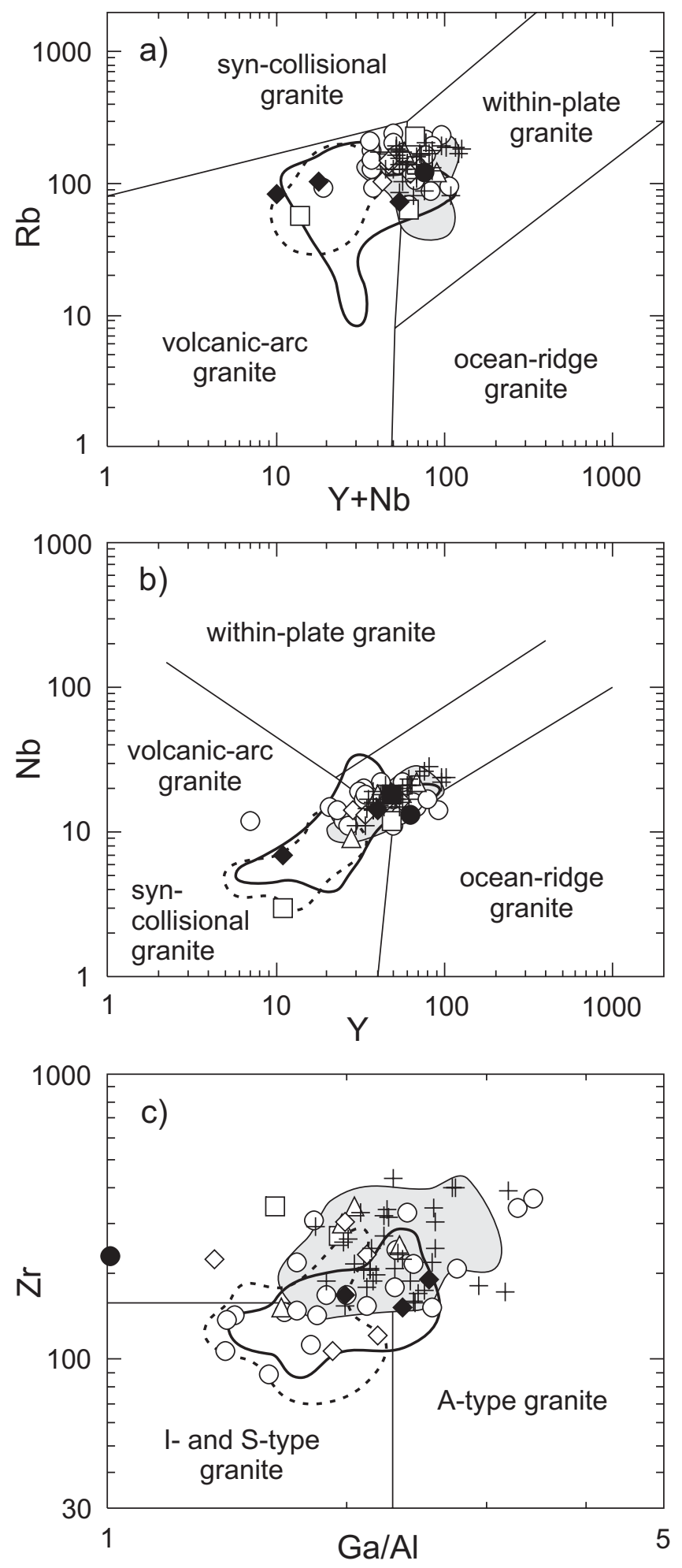

Fig. 7 Plots of (a) Rb - $\mathrm{Y}+\mathrm{Nb}$, (b) $\mathrm{Nb}-\mathrm{Y}$, and (c) $\mathrm{Zr}$ - Ga/Al for samples with more than $65 \% \mathrm{SiO}_{2}$ (intermediate to felsic). Field in (a) and (b) are from Pearce et al. (1984), and in (c) from Whalen et al. (1987). Symbols and sources of chemical data are as in Fig. 5.
5). Although $\mathrm{Na}_{2} \mathrm{O}$ and $\mathrm{K}_{2} \mathrm{O}$ can be mobile during alteration and weathering, petrographic observations showed no significant differences in these rocks that might be expected to result in the systematic differences in the oxide abundances, so the observed differences are considered to be significant. The ca. $555 \mathrm{Ma}$ volcanic and plutonic units of the New River terrane also show most similarity in major element compositions to the ca. 560-550 Ma Caledonia terrane units, but have higher $\mathrm{K}_{2} \mathrm{O}$ contents in the most felsic samples (Fig. $5 \mathrm{~g}$ ). The number of samples (5) from ca. 625 Ma plutonic units in the New River terrane is too small to make any generalizations or comparisons with plutonic units of similar age in the Caledonia terrane, although the overall compositional variations are similar to those in the ca. $620 \mathrm{Ma}$ Caledonia terrane suite.

In terms of trace elements, the ca. $620 \mathrm{Ma}$ Caledonia terrane and ca. 545-525 Ma Brookville terrane suites have similarities in $\mathrm{Rb}, \mathrm{Zr}, \mathrm{Nb}$, and $\mathrm{Y}$ (Fig. 6), and hence plot in similar positions of chemical affinity and tectonic setting discrimination diagrams, consistent with their similar tectonic settings. However, the Brookville suite throughout the full range of $\mathrm{SiO}_{2}$ contents has lower $\mathrm{Ba}$ and $\mathrm{Sr}$ than the Caledonia suite. Samples from ca. 625 Ma plutonic units in the New River terrane have trace element signatures similar to those in the ca. $620 \mathrm{Ma}$ Caledonia suite, especially the low $\mathrm{Y}$ and $\mathrm{Zr}$ values in intermediate samples (Fig. 6e, f), and a continental margin subduction zone setting is suggested (Fig. 7).

The ca. 560-550 Ma Caledonia volcanic and plutonic units have lower $\mathrm{Ba}$ (similar to the Brookville plutons in this case) and $\mathrm{Sr}$, but higher $\mathrm{Zr}, \mathrm{Nb}$, and $\mathrm{Y}$ than the ca. $620 \mathrm{Ma}$ suite from the same terrane. The difference is consistent with the inferred within-plate setting and enhanced "A-type" character of the ca. 560-550 Ma suite compared to the volcanic-arc signature and more I-type features of ca. $620 \mathrm{Ma}$ Caledonia terrane plutons. Barr and White $(1996,1999)$ interpreted the change to be related to later extension within a former subduction environment. The opposite pattern is true for the Brookville terrane, in which the younger ca. 545-525 Ma plutons have a clear subduction-related signature, whereas the older ca. 555-545 Ma Dipper Harbour Formation and related plutons have more extensional characteristics. The change was recognized by White et al. (2002), who suggested that magmatism in the Brookville terrane began with A-type magmatism, presumably related to crustal extension, but quickly evolved into a regime of continental margin-type subduction. Subduction continued to about $525 \mathrm{Ma}$ and generated the voluminous gabbroic to monzogranitic (but dominantly tonalitic and granodioritic) plutons that comprise most of the Golden Grove Plutonic Suite.

Trace elements show some differences between the ca. 560$550 \mathrm{Ma}$ units of the Caledonia terrane and the ca. $555-545 \mathrm{Ma}$ units of the Brookville terrane, in spite of their similar ages and inferred tectonic settings, in that the Brookville terrane units tend to have higher $\mathrm{Ba}, \mathrm{Rb}$, and $\mathrm{Nb}$ (Fig. 6b, d, e). Comparing both of these units to the ca. $555 \mathrm{Ma}$ volcanic and plutonic rocks of the New River terrane, some differences are also apparent, such as higher Rb in New River terrane units (Fig. 6b), 
although again the inferred tectonic setting is similar. It is interesting that the ca. 555-545 Ma felsic units of the Brookville terrane and the ca. $555 \mathrm{Ma}$ units of the New River terrane show more similarity to one another than to units of similar age in the Caledonia terrane. However, some subtle differences are apparent between the New River and Brookville terrane units, such as a tendency for lower $\mathrm{Y}$ and $\mathrm{Zr}$ in the New River terrane samples (Fig. 6e, f), and lower Ga/Al ratios (Fig. 7c).

Too few data are available from the ca. $555 \mathrm{Ma}$ Lobster Brook and ca. $540 \mathrm{Ma}$ Simpsons Island formations of the New River terrane to make any generalizations, except that they are broadly comparable to the other units and probably also formed in extensional tectonic settings. It appears that wherever these units were located relative to one another in the Late Neoproterozoic, all were forming in an extensional regime. However, it should be noted that Johnson and McLeod (1996) considered that the Simpsons Island Formation formed in a subduction environment, based on analyses from mafic samples in the unit. It is apparent that more detailed studies of these units are needed in order to make more meaningful interpretations.

It is important to emphasize that the lithological components of the Coldbrook Group and associated plutons also serve to distinguish them from units of overlapping age in the Brookville and New River terranes. The Coldbrook Group and associated plutons range in composition from basalt/gabbro to rhyolite/granite, with abundant dacitic volcanic units. None of these rocks match the almost entirely rhyolitic/granitic Dipper Harbour Formation and related ca. 555-545 Ma plutons. Although not yet described in detail, it appears that lithological similarities are more apparent between the Dipper Harbour Formation and related plutons and the ca. $555 \mathrm{Ma}$ plutonic and volcanic rocks of the Leavitts Head Formation and Ragged Falls suite in the New River terrane, which are also mainly rhyolitic and granitic.

\section{Isotopic data}

Previous studies (e.g., Whalen et al. 1994, 1996; Samson et al. 2000) suggested that $\mathrm{Sm}-\mathrm{Nd}$ isotopic data indicate differences among terranes in southern New Brunswick. As part of the present study, two additional samples from the Brookville terrane and one from the New River terrane were analysed for Sm and Nd isotopes (Table 3). Samples from the Lutes Mountain and McCarthy Point plutons (Brookville terrane) have small positive epsilon $\mathrm{Nd}$ values of 0.87 and 0.89 , whereas the Blacks Harbour granite sample (New River terrane) has a lower epsilon $\mathrm{Nd}$ of -3.13 . These new data have been plotted together with pre-existing data against age on Fig. 8 , and fit in with the trend for samples from the Brookville and New River

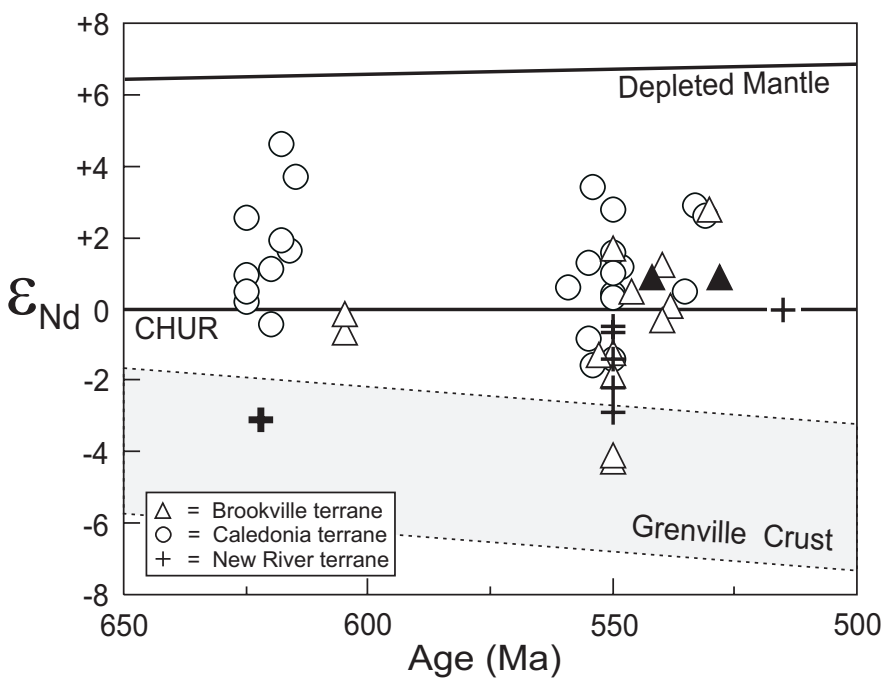

Fig. 8 Plot of epsilon $\mathrm{Nd}$ against age for samples from the New River, Brookville, and Caledonia terranes. Heavy black cross and filled triangles are data from Table 3 (this study). Other data are from the compilation of Samson et al. (2000) and Barr et al. (2000).

Table 3. New Sm-Nd data for samples from the Brookville and New River terranes.

\begin{tabular}{lccccccccc}
\hline \multicolumn{1}{c}{ Unit } & \multicolumn{2}{c}{ Age $(\mathrm{t})$} & $\mathrm{Nd}$ & $\mathrm{Sm}$ & & & \\
& Sample \# & $\mathrm{Ma}$ & $(\mathrm{ppm})$ & $(\mathrm{ppm})$ & ${ }^{147} \mathrm{Sm} /{ }^{144} \mathrm{Nd}$ & ${ }^{143} \mathrm{Nd} /{ }^{144} \mathrm{Nd}$ & $2 \sigma$ & Epsilon $(\mathrm{t})$ & $\mathrm{T}_{\mathrm{DM}}$ \\
\hline Lutes Mtn Diorite & $\mathrm{NB} 00-11$ & 542 & 15.79 & 3.714 & 0.1422 & 0.512489 & 4 & 0.87 & $1179 \mathrm{Ma}$ \\
McCarthy Pt Granodiorite & $\mathrm{NB99-5}$ & 528 & 16.39 & 3.510 & 0.1295 & 0.512451 & 5 & 0.89 & $1073 \mathrm{Ma}$ \\
Blacks Harbour Granite & $\mathrm{NB99-2}$ & 622 & 21.73 & 3.782 & 0.1052 & 0.512105 & 3 & -3.13 & $1316 \mathrm{Ma}$ \\
\hline
\end{tabular}

Notes: Analyses by Alain Potrel, Memorial University of Newfoundland. Concentration data are standard ICP-MS analyses and are precise to $\pm 5 \%(2 \sigma)$ (Longerich et al. 1990). Ratios of ${ }^{147} \mathrm{Sm} /{ }^{144} \mathrm{Nd}$ were measured directly by high-precision ICP-MS with estimated precision of $\pm 0.5 \%(2 \sigma) .2 \sigma$ error in last two figures in brackets. Ratios of ${ }^{143} \mathrm{Nd} /{ }^{144} \mathrm{Nd}$ were measured by thermal ionization mass spectrometry with errors of $\pm 0.000020(2 \sigma)$ or better. $2 \sigma$ error in last two figures in brackets. Isotopic data were corrected to the LaJolla value of 0.511850 . $\mathrm{T}_{\mathrm{DM}}$ model age was calculated according to the model of DePaolo (1988). Epsilon Nd values were calculated with respect to CHUR using a present-day ${ }^{143} \mathrm{Nd} /{ }^{144} \mathrm{Nd}$ ratio of 0.512638 and ${ }^{147} \mathrm{Sm} /{ }^{144} \mathrm{Nd}$ ratio of 0.196593 . Sample locations and geochemistry for the first two samples are presented in White et al. (2002), and for NB99-2 in Table 2, this paper. 


\section{Laurentia and accreted}

Ordovician arcs

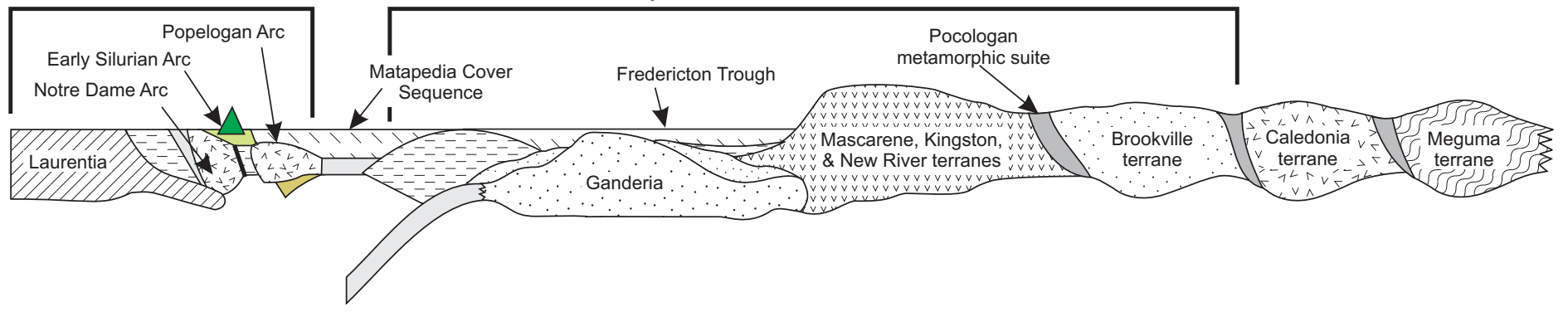

Fig. 9 A schematic diagram showing tectonic elements in New Brunswick. The Brookville, Caledonia (Avalon terrane sensu stricto), and Meguma terranes are inferred to have docked sequentially and independently against the New River-MascareneKingston terranes, representing the margin of Ganderia. Together, Ganderia, Mascarene, New River, Kingston, and Brookville terranes have been termed Composite Ganderia or Bras d'Oria. The area from the Fredericton Trough to Laurentia is taken from van Staal et al. $(1996,1998)$.

terranes which have generally lower epsilon $\mathrm{Nd}$, and more samples with negative values, than the Caledonia terrane (Fig. 8).

The data generally support the suggestion that magma generation was different in the different terranes, although the ranges show some overlap. Too few chemical data are available to provide a characterization of the ca. $620 \mathrm{Ma}$ plutons in the New River terrane relative to ca. $625-615 \mathrm{Ma}$ plutons in the Caledonia terrane, but the negative signature (epsilon $\mathrm{Nd}-3.13$ ) of the Blacks Harbour granite is a major contrast compared to the signatures of ca. 625-615 Ma units in Caledonia terranes which average 1.67. Similarly, the younger suite also differ on average, with ca. 560-550 Ma plutons in the Caledonia terrane having average epsilon $\mathrm{Nd}$ of 1.0 , units of ca. 555 to $525 \mathrm{Ma}$ age in the Brookville terrane an average value of -0.57 , and in the New River terrane of -1.28 .

Kerr et al. (1995) showed that mainly positive epsilon $\mathrm{Nd}$ signatures characterize the Avalon terrane sensu stricto in its type area in Newfoundland, whereas negative values are typical of the adjacent Gander zone. Whalen et al. (1996) showed that in southern New Brunswick, Silurian and Devonian plutons have more transitional values in the vicinity of the boundary between the Mascarene and St. Croix terranes, which they considered to be the Avalon - Gander boundary, and that Silurian and Devonian rocks of the Saint George Batholith and the Kingston terranes have high values typical of "Avalon". However, these values are too high to have been derived from the crust of Avalon terrane sensu stricto, which would have had mainly negative values in the Silurian-Devonian. It is likely that the juvenile signatures of those rocks are related to the mainly mantle source, with little crustal contamination, and the change to lower values in plutons to the northwest could be related to increasing crustal contamination in areas of less voluminous magma generation. Our new isotopic data from Neoproterozoic - Cambrian igneous units support previous studies (e.g., Samson et al. 2000) which suggested that the boundary of the Avalon terrane coincides with the Caledonia
- Clover Hill fault. The data further suggest that the Brookville and New River terranes have different crustal components, but more complete study of units is needed in the New River terrane to further assess the significance of the difference.

\section{DISCUSSION AND CONCLUSIONS}

Models for building of the Appalachian orogen (and its continuation in the Caledonides of Europe) typically show details for Paleozoic tectonic activity in the central portion of the orogen (e.g. van Staal et al. 1998; Armstrong and Owen 2001), but infer that much of the outboard area (variously termed Avalon zone, Avalon composite terrane, Avalon microcontinent, or Avalonia), behaved as a single block in the Paleozoic. Some authors have explicitly or implicitly linked the components of the Avalon composite terrane by events in the Late Proterozoic (Dostal et al. 1996; Murphy et al. 1999; Keppie et al. 2000). The overlap in ages among igneous units in these areas, as illustrated for example in Fig. 4, makes it tempting to correlate broadly on the basis of overlapping or near-overlapping age. However, as demonstrated by the data compiled here, the relationships among various igneous components of the "Avalon composite terrane" of similar ages are by no means clear. Differences in rock assemblages and chemical features, in some cases subtle, suggest that such igneous activity may have been related to the positions of these areas on active continental margins in the late Neoproterozoic, but that these margins were on different continents.

The model of van Staal et al. (1998) depicted the Cambrian through Silurian evolution of the orogen through interaction of Laurentia with Ganderia and various intervening oceanic and volcanic arc elements. Van Staal et al. (1998) suggested that Ganderia travelled with the Avalonian terranes as one microcontinent, but implied that Ganderia is a crustal block different from Avalon. Armstrong and Owen (2001) followed a similar theme, and referred to this area as Avalonia 
in the United Kingdom and Ireland. They showed several components in Avalonia, including Leinster -Lakesman, Monian terrane(s), and Avalon Terrane, the latter area most likely equivalent to the Avalon terrane sensu stricto of the present paper. They acknowledged that Avalonia may have had a complex Paleozoic history, but implied that at least the Monian terrane(s) and Avalon Terrane were together from the late Cambrian. However, the presence of Silurian arc-related igneous activity within the "Avalon composite terrane", such as in the Kingston terrane in southern New Brunswick, suggests a more complex history (Barr et al. 2002). Barr et al. (2002) suggested that the Kingston terrane and adjacent Pocologan metamorphic suite represent an arc and accretionary complex formed on the margin of Ganderia in the Silurian, presumably related to the docking of the Brookville terrane. The differences between Late Proterozoic to Early Cambrian magmatic histories in the Brookville and New River terranes support this interpretation, in the same way as differences between the Brookville and Caledonia terranes suggest that they too were separate, perhaps until the Silurian or Devonian (Barr and White 1996).

Viewing "Avalonia" as a composite of separate terranes that arrived sequentially and separately during the Silurian and Devonian, followed by the Meguma terrane (Fig. 9), helps to explain the long duration of the "Acadian orgeny" in Maine (Robinson et al. 1998; Tucker et al. 2001). This scenario implies that the juxtaposition of these outboard terranes or crustal blocks in the Silurian and Devonian was mainly by transcurrent motions, and such lateral adjustments, with local transtension and transpression, continued into the Carboniferous.

\section{ACKNOWLEDGEMENTS}

This project has been funded mainly by Natural Sciences and Engineering Research Council of Canada research grants to S.M. Barr. Research agreements with the NB Department of Natural Resources funded the U-Pb geochronology reported here. We are grateful to Les Fyffe, Sue Johnson, and Malcolm McLeod for stimulating field trips and discussions that have contributed much to our current understanding of the geology of southern New Brunswick. Les Fyffe provided some of the samples for geochemistry from the southern part of the New River terrane. Malcolm McLeod collected the sample for dating from Adam Island. We thank journal reviewers Susan Johnson and Damian Nance for their insightful and helpful comments which led to significant clarifications and improvements in the manuscript.

\section{References}

Armstrong, H.A., \& Owen, A.W. 2001. Terrane evolution of the paratectonic Caledonides of northern Britain. Journal of the Geological Society, London, 158, pp. 475-486.

Barr, S.M., \& White, C.E. 1996. Contrasts in late Precambri- an-early Paleozoic tectonothermal history between Avalon Composite Terrane sensu stricto and other peri-Gondwanan terranes in southern New Brunswick and Cape Breton Island, Canada. In Avalonian and related peri-Gondwanan terranes of the Circum-North Atlantic. Edited by R.D. Nance and M.D. Thompson. Geological Society of America Special Paper 304, pp. 95-108.

BArr, S.M., \& White, C.E. 1999. Field relations, petrology, and structure of Neoproterozoic rocks in the Caledonian Highlands, southern New Brunswick, Canada. Geological Survey of Canada Bulletin 530, $101 \mathrm{p}$.

Barr, S.M., Bevier, M.L., White, C.E., \& Doig, R. 1994. Magmatic history of the Avalon terrane of southern New Brunswick, Canada, based on U-Pb (zircon) geochronology. Journal of Geology, 102, pp. 399-409.

BARr, S.M., RAEside, R.P., White, C.E., 1998. Geological correlations between Cape Breton Island and Newfoundland. Canadian Journal of Earth Sciences, 35, pp. 1252-1270.

Barr, S.M., Hamilton, M.A., White, C.E., \& Samson, S.D. 2000. A Late Neoproterozoic age for the Caledonia Mountain Pluton, a high Ti-V layered gabbro in the Caledonia (Avalon) terrane, southern New Brunswick. Atlantic Geology, 36, pp. 157-166.

BarR, S.M., White, C.E., \& Miller, B.V. 2002. The Kingston terrane, southern New Brunswick, Canada: Evidence for a Silurian volcanic arc. Geological Society of America Bulletin,114, pp. 964-982.

Barr, S.M., Davis, D.W., Kamo, S., \& White, C.E. 2003. Significance of $\mathrm{U}-\mathrm{Pb}$ ages of detrital zircon in quartzite from peri-Gondwanan terranes, New Brunswick and Nova Scotia, Canada. Precambrian Research, in press

Bevier, M.L., \& BARR, S.M. 1990. U-Pb age constraints on the stratigraphy and tectonic history of the Avalon terrane, New Brunswick, Canada. Journal of Geology, 98, pp. 53-63.

Bevier, M.L., White, C.E., \& BARR, S.M. 1990. Late Precambrian U-Pb ages for the Brookville Gneiss, southern New Brunswick. Journal of Geology, 98, pp. 955-965

Currie, K.L. 1988. The western end of the Avalon zone in southern New Brunswick. Maritime Sediments and Atlantic Geology, 24, pp. 339-352.

CURrie, K.L. 1997.Geological map of the Saint John - Saint George region (with marginal notes). Geological Survey of Canada, Open File Report 3418.

Currie, K.L., \& HunT, P.A. 1991. Late Precambrian activity near Saint John, New Brunswick, in Radiogenic Age and Isotopic Studies. Report 4, Geological Survey of Canada, Paper 90-2, pp. 11-17

Currie, K.L., \& McNicoll, V.J. 1999. New data on the age and geographic distribution of Neoproterozoic plutons near Saint John, New Brunswick. Atlantic Geology, 35, pp. 157-166.

Dallmeyer, R.D., \& NANCE, R.D. 1992. Tectonic implications of ${ }^{40} \mathrm{Ar} /{ }^{39} \mathrm{Ar}$ mineral ages from Late Precambrian-Cambrian plutons, Avalon Composite Terrane, southern New Brunswick, Canada. Canadian Journal of Earth Sciences, 29, pp. 2445-2462. 
Dallmeyer, R.D., Doig, R., Nance, R.D., \& Murphy, J.B. 1990. ${ }^{40} \mathrm{Ar} /{ }^{39} \mathrm{Ar}$ and U-Pb mineral ages from the Brookville Gneiss and Green Head Group: implications for terrane analysis and evolution of Avalonian "basement" in southern New Brunswick. Atlantic Geology, 26, pp. 247-257.

DePaolo, D.J. 1988. Neodymium isotope geochemistry: an introduction. Springer-Verlag, New York. 154p.

Dorais, M.J., Wintsch, R.P., Becker, H. 2001. The Massabesic Gneiss Complex, New Hampshire: A study of a portion of the Avalon terrane. American Journal of Science, 301, pp. 657-682.

Dostal, J., Keppie, J.D., Cousins, B.L., \& Murphy, J.B. 1996. 550-580 Ma magmatism in Cape Breton Island (Nova Scotia, Canada): the product of NW-dipping subduction during the final stages of assembly of Gondwana. Precambrian Research, 76, pp. 96-113.

Eby, G.N., \& CurRIE, K.L. 1996. Geochemistry of the granitoid plutons of the Brookville terrane, Saint John, New Brunswick, and implications for development of the Avalon Zone. Atlantic Geology, 32, pp. 247-268.

Fyffe, L.R., Pickerill, R.K., \& Stringer, P. 1999. Stratigraphy, sedimentology and structure of the Oak Bay and Waweig formations, Mascarene basin: implications for the Paleotectonic evolution of southwestern New Brunswick. Atlantic Geology, 35, pp. 59-84.

Helmstaedt, H. 1968. Structural analysis of the Beaver Harbour area, Charlotte County, New Brunswick. Unpublished $\mathrm{PhD}$ thesis, University of New Brunswick, Fredericton, NB.

Hofmann, H.J. 1974. The stromatolite Archaeozoon acadiense from the Proterozoic Green Head Group of Saint John, New Brunswick. Canadian Journal of Earth Sciences, 11, pp. 1098-1115.

Isachsen, C.E., Bowring, S.A., LANDing, E., SAmson, S.D. 1994. New constraint on the division of Cambrian time. Geology, 22, 496-498.

Johnson, S.C. 2001. Contrasting geology in the Pocologan River and Long Reach areas: implications for the New River belt and correlations in southern New Brunswick and Maine. Atlantic Geology, 37, pp. 61-79.

Johnson, S.C. 2003. The composite New River belt, southwestern New Brunswick. Geological Society of America, 2003 Abstracts with Programs v. 34, p. 18.

Johnson, S.C., \& McLeod, M.J. 1996. The New River Belt: A unique segment along the western margin of the Avalon composite terrane, southern New Brunswick, Canada. In Avalonian and related peri-Gondwanan terranes of the Circum-North Atlantic. Edited by R.D. Nance and M.D. Thompson. Geological Society of America Special Paper 304, pp. 149-164.

Keppie, J.D., Dostal, J., Dallmeyer, R.D., \& Doig, R. 2000. Superposed Neoproterozoic and Silurian magmatic arcs in central Cape Breton Island, Canada: geochemical and geochronological constraints: Geological Magazine, 137, pp. 137-153.

Kerr, A., Jenner, G.A., \& Fryer, B.J. 1995. Sm-Nd isotopic geochemistry of Precambrian to Paleozoic granitoid suites and the deep-crustal structure of the southeast margin of the Newfoundland Appalachians. Canadian Journal of Earth Sciences, 32, pp. 224-245.

LANDING, E., 1996. Avalon: Insular continent by the latest Precambrian. In Avalonian and related peri-Gondwanan terranes of the Circum-North Atlantic. Edited by R.D. Nance and M.D. Thompson. Geological Society of America Special Paper 304, pp. 29-63.

Landing, E., \& Westrop, S.R.1998. Avalon 1997 - The Cambrian Standard. New York State Museum Bulletin 492, 92 p.

Landing, E., Bowring, S.A., Davidek, K.L., Westrop, S.R., Geyer, E., \& Heldmaier, W. 1998. Duration of the Early Cambrian: U-Pb ages of volcanic ashes from Avalon and Gondwana. Canadian Journal of Earth Sciences, 35, pp. 329-338.

Longerich, H., Jenner, G.A., Fryer, B.J., \& Jackson, S.E. 1990. Inductively coupled plasma- mass spectrometric analysis of geochemical samples. A critical evaluation based on case studies: Chemical Geology, 83, pp. 105-118.

LUDWIG, K.R. 1989. Pb-Dat: A computer program for processing raw $\mathrm{Pb}-\mathrm{U}-\mathrm{Th}$ isotope data. US Geological Survey OpenFile Report 88-557, 34 p.

McLeod, M.J., Johnson, S.C. ANd Krogh, T.E. U-Ph dates from southern New Brunswick. Atlantic Geology, in press.

Middlemost, E.A.K. 1975. The basalt clan: Earth Science Reviews, 11, p. 337-364.

Miller, B.V., Samson, S.D., \& D’Lemos, R.S. 2001. U-Pb geochronological constraints on the timing of plutonism, volcanism, and sedimentation, Jersey, Channel Islands, UK. Journal of the Geological Society of London, 158, pp. 243-252.

Murphy , J.B., Keppie, J.D., Dostal, J., \& NAnce, R.D. 1999. Neoproterozoic - early Paleozoic evolution of Avalonia. In Laurentia-Gondwana Connections before Pangea. Edited by V.A. Ramos and J.D. Keppie. Geological Society of America Special Paper 336, pp. 253-266.

Nance, R.D., \& DallmeYer, R.D. 1994. Structural and ${ }^{40} \mathrm{Ar} /{ }^{39} \mathrm{Ar}$ mineral age constraints for the tectonothermal evolution of the Green Head Group and Brookville Gneiss, southern New Brunswick, Canada: implications for the configuration of the Avalon Composite terrane. Geological Journal, 29, pp. 293-322.

Nance, R.D., Murphy, J.B., \& Keppie, J.D. 2002. A Cordilleran model for the evolution of Avalonia. Tectonophysics, 352, pp. 11-31.

Nowlan, G.S., McCracken, A.D., \& Mcleod, M.J. 1997. Tectonic and paleogeographic significance of Late Ordovician conodonts in the Canadian Appalachians. Canadian Journal of Earth Sciences, 34, 1521-1537.

Окицттсн, A.V. 2002. Geological time chart 2002. Geological Survey of Canada Open File 3040. National Earth Science Series - Geological Atlas. Revision.

Pearce, J.A., Harris, N.B., \& Tindle, A.G. 1984. Trace element discrimination diagrams for the tectonic inter- 
pretation of granitic rocks. Journal of Petrology, 25, pp. 956-983.

Robinson, P., Tucker, R.D., Bradley, Berry, H.N. IV, AND Osberg, P.H. 1998. Paleozoic orogens in New England, USA. GFF, 120, pp. 119-148.

SAMSON, S.D., BARR, S.M., \& White, C.E. 2000. Nd isotopic characteristics of terranes within the Avalon zone, southern New Brunswick. Canadian Journal of Earth Sciences, 37, pp.1039-1052.

Slauenwhite, D. 1999. Regional Geochemical Centre. Website http://www.stmarys.ca/academic/science/geology/ geochemctr/brochure.html.

Tucker, R.D., Osberg, P.H., \& Berry, H.N. IV. 2001. The geology of a part of Acadia and the nature of the Acadian orogeny across central and eastern Maine. American Journal of Science, 301, pp. 205-260.

TANOLI, S.K., \& PickeriLl, R.K. 1988. Lithostratigraphy of the Cambrian-Lower Ordovician Saint John Group, southern New Brunswick. Canadian Journal of Earth Sciences, 25, pp. 669-690.

van Staal, C.R., Sullivan, R. W., \& Whalen, J.B. 1996. Provenance and tectonic history of the Gander Zone in the Caledonian/Appalachian orogen: Implications for the origin and assembly of Avalon. In Avalonian and related periGondwanan terranes of the Circum-North Atlantic. Edited by R.D. Nance and M.D. Thompson. Geological Society of America Special Paper 304, pp. 347-367.

van Staal, C.R., Dewey, J.F., MacNiocaill, C., \& McKerRow, W.S., 1998. The Cambrian - Silurian tectonic evolution of the northern Appalachians and British Caledonides: history of a complex west and southwest Pacific-type segment of Iapetus. In Lyell: the Past is the Key to the Present. Edited by D.J. Blundell and A.C. Scott. Geological Society of London Special Publication 143, pp. 199-242.

Whalen, J.B., Currie, K.L., \& Chappell, B.W. 1987. A-type granites: geochemical characteristics, discrimination and petrogenesis. Contributions to Mineralogy and Petrology, 95, pp. 407-419.
Whalen, J.B., Jenner, G.A., Currie, K.L., Barr, S.M., Longstaffe, F.J., \& Hegner, E. 1994. Geochemical and isotopic characteristics of granitoids of the Avalon Zone, southern New Brunswick: Possible evidence for repeated delamination events. Journal of Geology, 102, pp. 269-282.

Whalen, J.B., Fyffe, L.R., Longstaffe, F.J., \& JENNER, G.1996. The position and nature of the Gander Avalon boundary, southern New Brunswick, based on geochemical and isotopic data from granitoid rocks. Canadian Journal of Earth Sciences, 33, pp. 129-139.

White, C.E. 1996. Geology, geochronology, and tectonic evolution of the Brookville terrane, southern New Brunswick. Unpublished PhD thesis, Dalhousie University, Halifax, Nova Scotia, 513p.

White, C.E., \& BARR, S.M., 1996, Geology of the Brookville terrane, southern New Brunswick, Canada. In Avalonian and related peri-Gondwanan terranes of the Circum-North Atlantic. Edited by R.D. Nance and M.D. Thompson. Geological Society of America Special Paper 304, pp. 95-108.

White, C.E., Barr, S.M., Jamieson, R.A., \& Reynolds, P.H. 2001. Neoproterozoic high-pressure/low-temperature metamorphic rocks in the Avalon terrane, southern New Brunswick, Canada. Journal of Metamorphic Geology, 19, p. 517-528.

White, C.E., Barr, S.M., Miller, B.V., Hamilton, M.A. 2002. Granitoid plutons of the Brookville terrane, southern New Brunswick: petrology, age, and tectonic setting. Atlantic Geology, 38, pp. 53-74.

Williams, H., 1978, Tectonic lithofacies map of the Appalachians: Memorial University Map No. 1, Department of Geology, Memorial University of Newfoundland, Canada.

Williams, H., 1979. The Appalachian Orogen in Canada. Canadian Journal of Earth Sciences, 16, pp. 792-807.

Zain EldeEn, U. 1991. The geology of the Dipper Harbour area, southern New Brunswick, Canada. Unpublished MSc. Thesis, Ohio University, Athens, Ohio, 151p.

Editorial responsibility: Ron K. Pickerill 
